\title{
Oxidative Stress Related to Plasmalemmal and Mitochondrial Phosphate Transporters in Vascular Calcification
}

\author{
Nhung Thi Nguyen ${ }^{1,2,3}$, Tuyet Thi Nguyen ${ }^{1,4, *(\mathbb{D})}$ and Kyu-Sang Park $1,2, * \mathbb{D}$ \\ 1 Department of Physiology, Wonju College of Medicine, Yonsei University, Wonju 26426, Korea; \\ nhung.nt@vinuni.edu.vn \\ 2 Mitohormesis Research Center, Wonju College of Medicine, Yonsei University, Wonju 26426, Korea \\ 3 Medical Doctor Program, College of Health Sciences, VinUniversity, Hanoi 12406, Vietnam \\ 4 Internal Medicine Residency Program, College of Health Sciences, VinUniversity, Hanoi 12406, Vietnam \\ * Correspondence: tuyet.nt@vinuni.edu.vn (T.T.N.); qsang@yonsei.ac.kr (K.-S.P.); \\ Tel.: +84-247-108-9779 (T.T.N.); +82-33-741-0294 (K.-S.P.)
}

Citation: Nguyen, N.T.; Nguyen, T.T.; Park, K.-S. Oxidative Stress Related to Plasmalemmal and Mitochondrial Phosphate Transporters in Vascular Calcification. Antioxidants 2022, 11, 494. https://doi.org/10.3390/ antiox11030494

Academic Editors: Lanrong Bi, K Michael Gibson and Guim Kwon

Received: 18 December 2021 Accepted: 28 February 2022 Published: 2 March 2022

Publisher's Note: MDPI stays neutral with regard to jurisdictional claims in published maps and institutional affiliations.

Copyright: () 2022 by the authors. Licensee MDPI, Basel, Switzerland. This article is an open access article distributed under the terms and conditions of the Creative Commons Attribution (CC BY) license (https:/ / creativecommons.org/licenses/by/ $4.0 /)$.

\begin{abstract}
Inorganic phosphate $(\mathrm{Pi})$ is essential for maintaining cellular function but excess of $\mathrm{Pi}$ leads to serious complications, including vascular calcification. Accumulating evidence suggests that oxidative stress contributes to the pathogenic progression of calcific changes. However, the molecular mechanism underlying Pi-induced reactive oxygen species (ROS) generation and its detrimental consequences remain unclear. Type III $\mathrm{Na}^{+}$-dependent Pi cotransporter, PiT-1/-2, play a significant role in Pi uptake of vascular smooth muscle cells. Pi influx via PiT-1/-2 increases the abundance of PiT-1/-2 and depolarization-activated $\mathrm{Ca}^{2+}$ entry due to its electrogenic properties, which may lead to $\mathrm{Ca}^{2+}$ and Pi overload and oxidative stress. At least four mitochondrial Pi transporters are suggested, among which the phosphate carrier $(\mathrm{PiC})$ is known to be mainly involved in mitochondrial Pi uptake. Pi transport via PiC may induce hyperpolarization and superoxide generation, which may lead to mitochondrial dysfunction and endoplasmic reticulum stress, together with generation of cytosolic ROS. Increase in net influx of $\mathrm{Ca}^{2+}$ and $\mathrm{Pi}$ and their accumulation in the cytosol and mitochondrial matrix synergistically increases oxidative stress and osteogenic differentiation, which could be prevented by suppressing either $\mathrm{Ca}^{2+}$ or Pi overload. Therapeutic strategies targeting plasmalemmal and mitochondrial Pi transports can protect against Pi-induced oxidative stress and vascular calcification.
\end{abstract}

Keywords: vascular calcification; oxidative stress; phosphate; calcium; mitochondria; transporters

\section{Introduction}

Vascular calcification includes intimal and medial calcification, which occur via two different pathological mechanisms. Intimal calcification involves the formation of atherosclerosis plaques with necrotic lipid core and activation of macrophages, which leads to endothelial cell inflammation. Blood flow is obstructed when the plaques rupture, causing ischemia. Medial calcification is an active and complex cell-mediated process characterized by the absence of inflammatory cells and is associated with inorganic phosphate (Pi) and calcium overload in vascular smooth muscle cells (VSMCs). It is also known as Mönckeberg's sclerosis and causes arterial stiffness and decreases the compliance of vessels, which is observed in aging individuals and those with chronic kidney disease and diabetes mellitus. Medial calcification can happen in the small arteries of the toes to large arteries such as the tibial, popliteal, and femoral arteries of the legs or the carotid arteries [1-3].

Research shows that several key events mediated by $\mathrm{Ca}^{2+}$ and Pi occur simultaneously in VSMCs. Under hyper-phosphatemic conditions, VSMCs are trans-differentiated into bone-like cells that express high levels of osteogenic markers, including Runt-related transcription factor 2 (Runx2), osteopontin (OPN), osteocalcin, alkaline phosphatase (ALP), SRY-Box transcription factor 9 (Sox9), and type II and X collagen (Col II and Col X), and 
low levels of $\alpha$-smooth muscle actin ( $\alpha$ SMA) and smooth muscle $22 \alpha$ (SM22 $\alpha$ ). Osteogenic trans-differentiation can be associated with other phenomena, including loss of inhibitors such as matrix Gla protein, pyrophosphate, and fetuin A, or enhancement of cell senescence features, such as DNA damage and oxidative stress.

So far, studies have described the pathogenesis of Pi-induced calcification related to osteogenic differentiation and apoptotic body formation in VSMCs. Some of them have emphasized the role of cytosolic and mitochondrial oxidative stress upstream of the upregulation of osteogenic genes and changes in calcification; however, the molecular mechanisms connecting high Pi levels with oxidative stress have not been elucidated. To understand the pathogenic processes underlying cellular Pi overload, research on how Pi enters the cytosol and is taken up by the mitochondrial matrix must be conducted.

The estimation of cytosolic and mitochondrial Pi concentration using ${ }^{31} \mathrm{P} N \mathrm{NR}$ and $\mathrm{LC} / \mathrm{MS} / \mathrm{MS}$ has been reported [4]. In insulin-secreting cells, $2.8 \mathrm{nmol} \mathrm{Pi} / \mathrm{mg}$ protein was found in the cytosol, while the mitochondrial Pi concentration (10 nmol $/ \mathrm{mg}$ protein) was much higher. Based on rough calculations using the cell volume and volume proportion of the mitochondrial fraction, the cytosolic and mitochondrial Pi concentrations are approximately $1.2 \mathrm{mM}$ and 9-12 $\mathrm{mM}$, respectively. Considering that the normal plasma Pi level is in the range of $1.12-1.45 \mathrm{mM}$, the $\mathrm{Na}^{+}$gradient across the plasma membrane might be enough to drive cellular $\mathrm{Pi}$ uptake through an $\mathrm{Na}^{+}-\mathrm{Pi}$ cotransport mechanism. However, Pi transport into the mitochondrial matrix has a steep uphill gradient, which could be closely affected by mitochondrial activities, but details about the transportation mechanism remain unclear. In this review, we introduced the pathophysiological characteristics of plasmalemmal Pi transporters and mitochondrial Pi carriers in vascular calcification, particularly focusing on the vicious cycle between Pi uptake and oxidative stress.

\section{Plasmalemmal Phosphate Transporters}

Mainly two solute carrier families, SLC34A and SLC20A, transport extracellular Pi across the plasma membrane (Figure 1), both of which use the chemical gradient of $\mathrm{Na}^{+}$to transport Pi [5-7]. The SLC34A family has three members, including sodium-phosphate cotransporter types IIa (NaPi-IIa, SLC34A1) and IIc (NaPiIIc, SLC34A3), which are mainly expressed in the brush border membrane of proximal tubules, and type IIb (NaPi-IIb, SLC34A2), which is primarily expressed in the gastrointestinal tract [5-9]. The SLC20A family consists of two members, PiT-1 (SLC20A1) and PiT-2 (SLC20A2), which are ubiquitously expressed in the human body [5-7,9]. The physiological role of the SLC34 family proteins in Pi transport has been extensively studied and well characterized, including in dietary Pi absorption in small intestinal epithelial cells and renal Pi reabsorption in proximal tubular cells [7,10-14]. The SLC20A family has been considered to play a housekeeping role in Pi homeostasis in various tissues [8]. However, recent studies have shown their pathological roles in vascular calcification [15-17] and Pi-induced apoptosis in endothelial cells, epithelial cells, and podocytes [18]; hence, they are suggested to be putative therapeutic targets for vascular calcification.

\subsection{SLC34A Family}

All members of the SLC34 family transport $\mathrm{HPO}_{4}{ }^{2-}$ preferentially with $\mathrm{Na}^{+}$, although the stoichiometry between $\mathrm{Na}^{+}$and Pi differs among the three members. A series of studies by Forster's group using the patch-clamp technique in Xenopus laevis oocytes showed that $\mathrm{NaPi}-\mathrm{IIa} / \mathrm{NaPi}-\mathrm{IIb}$ are electrogenic and that $\mathrm{NaPi}$-IIc is electroneutral with $\mathrm{Na}$ :Pi stoichiometry of 3:1 and 2:1, respectively $[5,6,8,9,14,19]$. Transport of $\mathrm{Na}^{+}$and $\mathrm{Pi}$ via SLC34 is affected by extracellular $\mathrm{pH}$, which influences the distribution of $\mathrm{H}_{2} \mathrm{PO}_{4}{ }^{-}$ or $\mathrm{HPO}_{4}{ }^{2-}[6,8,19]$. This family mostly consists of functional monomers, with some occasional dimers or tetramers [6,8]. The members of this family are composed of 599 to 640 amino acids $[6,19]$ with 12 transmembrane domains. Both the C- and N-termini are intracellular [6], while the linker region is located on the extracellular side. NaPi-IIa and 
$\mathrm{NaPi}$-IIc, expressed abundantly in the apical membrane of proximal tubules, play essential roles in Pi reabsorption.

Type II NaPi Cotransporters

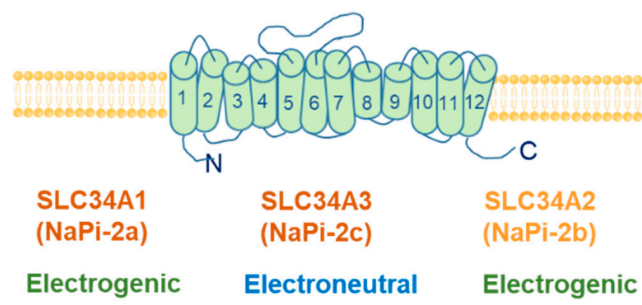

Preferred Pi species: $\quad \mathrm{HPO}_{4}{ }^{2}$

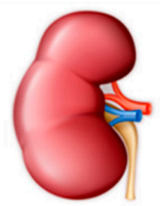

Proximal tubule Pi reabsorption

Intestine Pi absorption
Type III NaPi Cotransporters

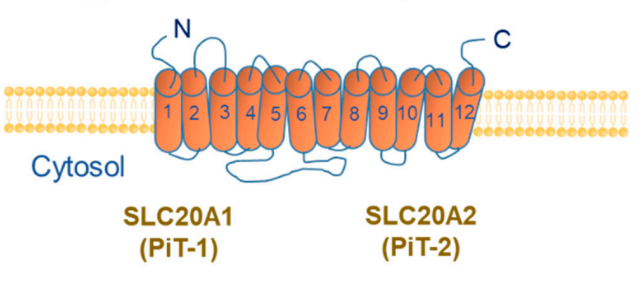

Electrogenic Electrogenic transport $\mathrm{HPO}_{4}{ }^{2-}$ or $\mathrm{H}_{2} \mathrm{PO}_{4}$

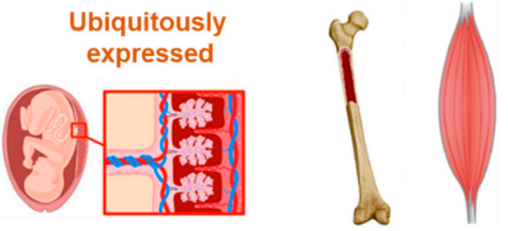

Placenta, Bone, muscle, spleen, bladder, etc

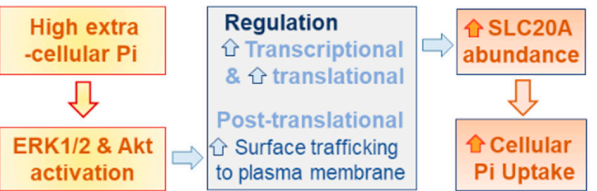

Figure 1. Plasmalemmal Pi transporters. The characteristics and tissue expressions of type II and III NaPi cotransporters are illustrated. The functional abundance of type II NaPi cotransporters are regulated by hormones, such as PTH and FGF23, in order to normalize serum Pi levels upon the alterations in dietary Pi. However, high extracellular Pi directly increases the functional abundance of type III NaPi cotransporters, leading to intracellular Pi accumulation.

A previous study has shown that mice lacking NaPi-IIa had low plasma Pi level with high urinary Pi excretion. In contrast, mice lacking NaPi-IIc did not show significant hypophosphatemia [9]. However, double knockout of both NaPi-IIa and NaPi-IIc resulted in serious renal Pi wasting, hypophosphatemia, and impaired skeletal mineralization, which are more severe than the phenotypes observed after knocking out only NaPi-IIa. In humans, loss of function mutations in SLC 34A1 and SLC34A3 cause hereditary hypophosphatemia, accompanied by increase in urinary loss of $\mathrm{Pi}$ [20]. NaPi-IIb expressed in the small intestine, regulates $\mathrm{Pi}$ absorption from the daily diet $[21,22]$. $\mathrm{NaPi}-\mathrm{Ilb}^{-/-}$mice died at the embryonic stage, whereas heterozygous mice showed lower plasma Pi level at 4 weeks. At 20 weeks, these heterozygous mice returned to normophosphatemia with increase in the abundance of NaPi-IIa and NaPi-IIc [22]. This indicated that Pi absorbed via NaPi-IIb is critical for survival during embryogenesis; however, compensatory upregulation of other types of $\mathrm{NaPi}$ transporters occur after birth.

\subsection{SLC20A Family}

The SLC20A family consists of two members, PiT-1 and PiT-2. These isoforms were initially discovered as retroviral receptor Glvr-1 (gibbon ape leukemia virus receptor) and Ram1 (rat amphotropic leukemia virus receptors) [23,24], and then later identified to be sodiumdependent phosphate transporters [25,26]. An electrophysiologic study in Xenopus oocytes has shown that Pi transport via SLC20A is electrogenic with $\mathrm{Na}^{+}: \mathrm{Pi}$ stoichiometry of 2:1, which is negligibly sensitive to $\mathrm{pH}$ and phosphonoformic acid (PFA) [8]. $\mathrm{H}_{2} \mathrm{PO}_{4}{ }^{-}$was suggested as the preferential form of Pi for transport via PiT-1/2 [8]. In HEK293 cells overexpressing PiT-1, extracellular Pi elicited inwardly rectifying currents, possibly leading to plasmalemmal depolarization. Pi-induced inward currents were exclusively extracellular and $\mathrm{Na}^{+}$-dependent, as indicated by increase in $\mathrm{Na}^{+}$uptake after addition of extracellular $\mathrm{Pi}$ [27]. However, in this 
study, Pi-induced inward currents were proportionally decreased by extracellular acidification ( $\mathrm{pH}$ 6.6), because of which more $\mathrm{H}_{2} \mathrm{PO}_{4}{ }^{-}$is produced from $\mathrm{HPO}_{4}{ }^{2-}$ [27]. These results implied that $\mathrm{H}_{2} \mathrm{PO}_{4}{ }^{-}$is more favored than other Pi species in Pi-transport via PiT-1, which, however, requires further clarification. PiT-1/2 has 12 transmembrane domains with both the C- and N-termini facing the extracellular space [8].

Mice lacking PiT-1 are embryonic lethal due to impaired hemopoiesis in the liver [28]. Interestingly, loss of function mutation in human SLC20A2 was responsible for basal ganglia calcification. The ectopic calcification can be explained by the high levels of extracellular Pi arising due to impaired cellular uptake via PiT-2, leading to the accumulation of calcium and Pi aggregates [29]. Consistently, SLC20A2 knockout mice also showed abnormal calcifications in the thalamus, basal ganglia, and cerebral cortex with maintained high Pi levels in cerebrospinal fluid (CSF) [29,30]. These findings suggested an essential role of PiT-2 in cellular Pi uptake for the maintenance of physiological Pi concentration in the extracellular environment.

Critical pathogenic roles of PiT-1/2 in vascular calcification have been demonstrated. In human VSMCs, shRNA-mediated knockdown of PiT-1 suppressed Pi-induced change in osteochondrogenic phenotype and vascular calcification. Similar observations were made in osteoblasts where PiT-1 knockdown reduced matrix mineralization and the expression of osteoblast markers such as OPN. As a compensatory change, the transcriptional level of PiT-2 increased two-fold in PiT-1-deleted VSMCs [31]. Silencing of either PiT-1 or PiT-2 protected from Pi-induced cytotoxicity in insulin-secreting cells, although PiT-1 suppression showed slightly more inhibition than PiT-2 silencing. Knockdown of both PiT-1 and PiT-2 successfully prevented mitochondrial superoxide generation, permeability transition (PT) pore opening, endoplasmic reticulum (ER) stress, and defective insulin secretion induced by the presence of high levels of Pi [27]. Double knockdown of PiT-1 and PiT-2 also abolished intracellular calcification by high Pi levels in rat aortic smooth muscle cells [32]. However, it has recently been reported that PiT-2 haploinsufficiency enhanced the development of vascular calcification, suggesting the protective role of PiT-2 against Pi-induced calcification [33]. Further investigations are required to clarify the pathophysiologic difference between PiT-1 and PiT-2 in VSMCs.

\subsection{Cytosolic Phosphate Exporter}

Unlike SLC34A and SLC20A, which mediate cellular $\mathrm{Na}^{+}$and Pi uptake, xenotropic and polytropic retrovirus receptor 1 (XPR1) was identified as a $\mathrm{Na}^{+}$-independent $\mathrm{Pi}$ exporter in mammalian cells, which was initially known as a receptor for murine leukemic viruses [34]. XPR1 contains the SPX domain in the N-terminus, which is involved in Pi sensing and transport [35]. Functional expression of XPR1 has been reported in brain tissues and neural stem cells, and an inactivating mutation in XPR1 results in basal ganglia calcification due to intra-neuronal Pi deposition [36]. Intriguingly, this phenotype is similar to that of Slc20a2 deletion, which induces extra-neuronal Pi accumulation as described above. A recent study has demonstrated the functional role of XPR1 in renal Pi reabsorption [37], although its transport and regulatory mechanisms remain unclear.

\subsection{Oxidative Stress Related to Plasmalemmal Pi Transporters}

Pi uptake with $\mathrm{Na}^{+}$via PiT-1 is an electrogenic process, resulting in net inward currents. PiT-1/2-mediated transport (symport) can depolarize plasma membrane potential, leading to the opening of voltage-gated calcium channels (VGCCs) highly expressed in VSMCs. Park's group reported that high Pi elicited dose-dependent plasmalemmal depolarization in rat aortic smooth muscle cells, which was prevented by silencing PiT-1/2 [22,37]. Depolarization of VSMCs elicited VGCC-mediated increase in cytosolic $\mathrm{Ca}^{2+}$ concentration $\left(\left[\mathrm{Ca}^{2+}\right]_{\mathrm{i}}\right)$, which was dependent on extracellular $\mathrm{Ca}^{2+}$ concentration and was blocked by VGCC inhibitors, verapamil or nimodipine. Furthermore, Pi-induced elevation in $\left[\mathrm{Ca}^{2+}\right]_{i}$ was abolished in cells lacking PiT-1/2 or by extracellular $\mathrm{Na}^{+}$free condition [22]. These findings indicated that cellular Pi uptake via PiT-1/2 leads to $\mathrm{Ca}^{2+}$ influx due to alteration of 
plasma membrane potential, consequently resulting in accumulation of $\mathrm{Ca}^{2+}$ and $\mathrm{Pi}$ in the cytosol. Both $\mathrm{Ca}^{2+}$ and Pi elevation accelerated reactive oxygen species (ROS) generation and vascular calcification, all of which were prevented by VGCC inhibitors or intracellular $\mathrm{Ca}^{2+}$ chelation [22].

The importance of PiT-1/2 in vascular calcification is evident from the increase in the expression level of PiT-1/2 in high Pi environment. In insulin-secreting cells and aortic smooth muscle cells, Pi increased the transcriptional and translational levels of PiT-1 and PiT-2 [27,32]. In addition, acute exposure to high Pi (for $<1 \mathrm{~h}$ ) facilitated the trafficking of PiT-1 to the plasma membrane, increasing functional Pi transporters for cellular Pi uptake. PiT-1/2, upregulated by Pi induction, may engage in a feed-forward amplification loop to accelerate pathogenic Pi overload in the cytosol.

Cellular Pi uptake via PiT-1/2 activates ERK1/2 and mTOR signaling and its downstream p70S6K in VSMCs and insulin-secreting cells [32]. Subsequently, activation of ERK1/2 and mTOR signaling participates in Pi-induced PiT-1/2 upregulation. Consistently, high Pi-induced oxidative stress via PiT-1/2 critically relies on ERK1/2-mTOR signaling. The molecular mechanism linking ERK1/2-mTOR signaling and calcification has not yet been elucidated; however, the translocation of NF-kB into the nucleus and upregulation of osteogenic genes, including RUNX2 and OPN were abolished by the blockade of either ERK1/2 or mTOR [32]. Taken together, PiT-1/2-mediated Pi uptake and the consequent activation of the ERK1/2-mTOR axis play an essential role in the vicious cycle of oxidative stress and vascular calcification.

\section{Mitochondrial Phosphate Transporters}

Pi acts as an essential molecule for many cellular functions. After entering the cytosol, Pi participates in cellular signaling such as those involving phosphorylation. In the mitochondria, Pi is used by ATP synthase to phosphorylate ADP after it enters the matrix via adenine nucleotide translocase (ANT). Furthermore, other than acting as a substrate for ATP synthesis, Pi also activates mitochondrial metabolism and oxidative phosphorylation. For ATP production and mitochondrial activation, Pi should be delivered from the cytosol via mitochondrial Pi transporters, such as phosphate carrier (PiC) [38], dicarboxylate carrier (DIC) [39], Mg-ATP / Pi transporter [40], and uncoupling protein-2 (UCP2) [41]. All these transporters are called mitochondrial carriers, which are a superfamily of nuclear-encoded proteins (solute carrier family 25; SLC25) located in the inner mitochondrial membrane [42]. The expression of these mitochondrial carriers varies among cells/tissues, and each of them possess specific characteristics (Figure 2); however, the pathophysiological role of mitochondrial Pi transporters in vascular calcification has not been investigated yet.

Extramitochondrial $\mathrm{Pi}$ has been known to increase mitochondrial membrane potential and superoxide generation in different types of cells, including VSMCs. Pharmacological inhibition of mitochondrial phosphate transporters using butylmalonate (BMA) or mersalyl attenuated mitochondrial hyperpolarization and superoxide production in insulin-secreting cells. Therefore, mitochondrial Pi transporters can be used as therapeutic targets to prevent or relieve high Pi-induced and oxidative stress-mediated osteogenic trans-differentiation and calcification. However, the pathophysiological role of mitochondrial Pi transporters in vascular calcification has not been investigated. Herein, we have introduced the molecular and functional properties of mitochondrial Pi transporters in tissues other than VSMCs. 


\section{Phosphate Carrier (PiC) Dicarboxylate Carrier (DIC)}

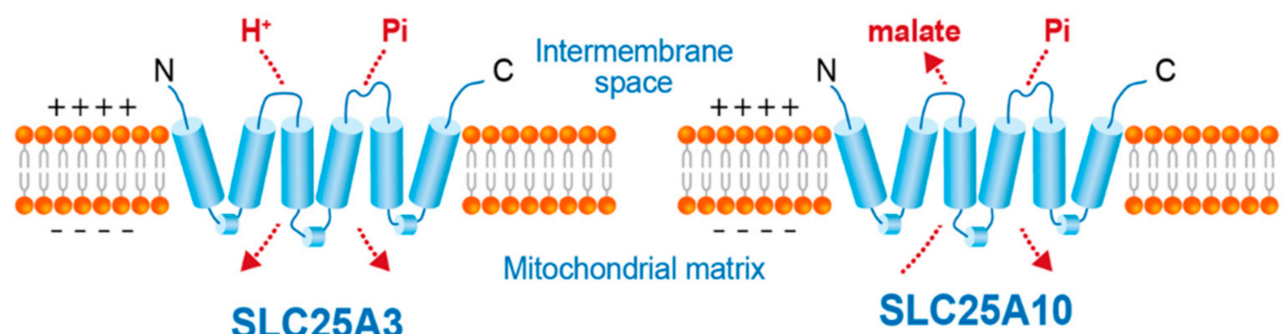

\section{Uncoupling Protein 2 (UCP2)}

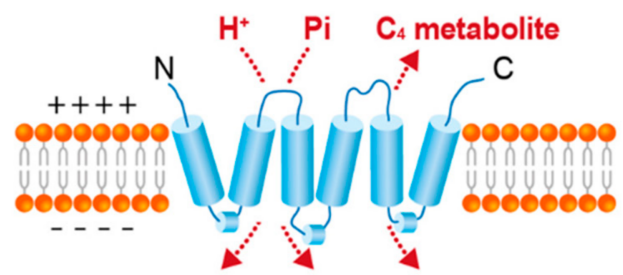

SLC25A8

\section{ATP-Mg/Pi transporter (SCaMC)}

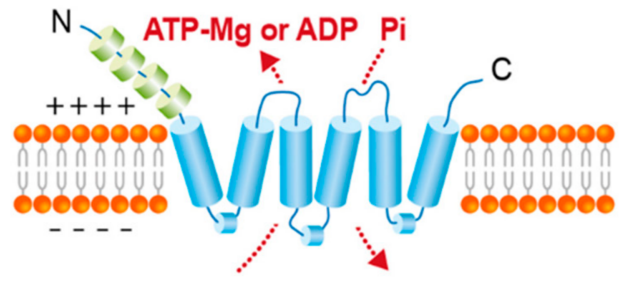

SLC25A23, 24, 25

Figure 2. Mitochondrial Pi transporters. Four mitochondrial carriers involved in Pi transport across the inner mitochondrial membrane and their hypothetical transport mechanisms are illustrated. PiC is the main route of mitochondrial Pi uptake driven by $\mathrm{pH}$ gradient. DIC exchanges dicarboxylate for $\mathrm{Pi}$ or other dicarboxylate, but also transport adenine nucleotides and glutathione. UCP2 performs Pi transport with $\mathrm{C}_{4}$ metabolites including malate, oxaloacetate, and aspartate. ATP-Mg/Pi transporter has EF hand domains in N-terminal leading to having a $\mathrm{Ca}^{2+}$ activated properties.

\section{1. $\mathrm{PiC}$}

$\mathrm{PiC}$ (SLC25A3) is encoded at chromosome 12q23 and exists as two isoforms, PiC-A and PiC-B, which are generated via alternative splicing of the exon 3 of SLC25A3 [43]. While isoform A is mainly found in the heart and skeletal muscle, low levels of isoform B is expressed in all tissues [44]. PiC has six transmembrane domains, and its $\mathrm{N}$ and $\mathrm{C}$ termini are present within the matrix [43], which is similar to the structure of other mitochondrial carrier proteins, such as ANT and UCP1 [42,45]. PiC is known to be the main route of Pi uptake into the mitochondria, which mediates electroneutral co-transport of $\mathrm{Pi}$ and $\mathrm{H}^{+}$; thus, $\mathrm{Pi}$ transport via $\mathrm{PiC}$ might be strictly driven by the $\mathrm{pH}$ gradient across the inner mitochondrial membrane [46]. It has been reported that the proximity of PiC with ANT and ATP synthase triggers the composition of the ATP synthasome in the mitochondrial cristae (Ko et al., 2003). This structure could be an important microdomain for ATP synthesis since ADP influx via ANT and Pi uptake via PiC are required for the generation of ATP using ATP synthase.

A recent report showed that $\mathrm{PiC}$ can transport not only $\mathrm{Pi}$ and $\mathrm{H}^{+}$but also $\mathrm{Cu}^{2+}$, which is required for cytochrome c oxidase activity (COX). Indeed, deletion of SLC25A3 resulted in isolated COX deficiency in murine and human cell lines, which was rescued by the addition of $\mathrm{Cu}^{2+}$ into the cell culture medium [47].

Fonyo and Ligeti suggested that $\mathrm{PiC}$ may be an important $\mathrm{H}^{+}$donor for the mitochondrial respiratory chain [48]. The role of PiC in ATP production and oxidative phosphorylation has been confirmed in studies using mice models of PiC depletion and loss-of-function mutation in human SLC25A3. Baines and Molkentin showed that repression of cardiac muscle-specific PiC exhibited cardiac hypertrophy and slightly reduced fractional shortening [49,50]. In these mice models, mitochondrial Pi uptake and ATP levels decreased, whereas the expression of electron transport chain (ETC) proteins, mitochon- 
drial respiration, and $\mathrm{Ca}^{2+}$ homeostasis were not significantly altered. In contrast, PiC expression increased 5-fold in cardiac-specific PiC transgenic mouse without apparent changes in protein levels of ANT, cyclophilin D and ATP synthase, as well as cardiac size and functions [49]. Additionally, $\mathrm{PiC}$ upregulation did not affect mitochondrial respiration in mitochondria isolated from cardiac-specific $\mathrm{PiC}$ transgenic mice [49]. The above findings regarding overexpression or suppression of $\mathrm{PiC}$ highlighted the lack of solid phenotypes, which indicated that the abundance of $\mathrm{PiC}$ does not limit the transport of Pi or other potential functions of $\mathrm{PiC}$ in the mouse heart. This is consistent with the reports that $\mathrm{PiC}$ has an exceptionally high turnover rate [51].

Studies on patients with SLC25A3 mutations, mainly PiC-A, revealed predominant involvement of cardiac and skeletal muscles, including hypertrophic cardiomyopathy and muscular dystonia [51-53]. This preference of the clinical phenotype can be explained by tissue-specific isoforms formed via alternative splicing. Compared to the features of other mitochondrial disorders causing cardiomyopathy, lack of neurocognitive involvement is one of the remarkable features of patients with SLC25A3 mutations [54].

The mitochondrial PT pore has been suggested to be a multi-protein complex composed of porin, ANT, and cyclophilin D [55]. Halestrap's group suggested that PiC is the essential component of the mitochondrial PT pore by interacting with cyclophilin D and ANT. $\mathrm{Ca}^{2+}$-triggered conformational change of the PiC, facilitated by cyclophilin $\mathrm{D}$, induces pore opening [56]. They also showed that Pi activates MPTP opening in energized and de-energized mitochondria [57]. In the absence of Pi, the sensitivity of PTP to $\mathrm{Ca}^{2+}$ or oxidative stress was not affected by the ablation of cyclophilin D [58]. However, the role of mitochondrial Pi transporters on PT pore opening remains controversial.

$\mathrm{PiC}$ was also found to functionally interact with the viral mitochondria-localized inhibitor of apoptosis (vMIA) [59]. vMIA inhibits apoptosis by recruiting Bax to mitochondria, thereby inducing its inactivation [60]. Furthermore, vMIA induces mitochondrial fragmentation, which requires $\mathrm{PiC}$ [61]. In addition, vMIA decreases mitochondrial respiration and ATP synthesis without changes in the abundance or activity of the $\mathrm{F}_{1} \mathrm{~F}_{0}$ ATP synthase or ANT. Despite the lack of any change in the abundance of PiC, vMIA suppresses PiC-mediated mitochondrial Pi uptake and Pi-stimulated ATP synthesis of host cells. Thus, the effect of viral infection on mitochondrial metabolism might be mediated via PiC [59].

In pancreatic $\beta$ cells, downregulation of $\mathrm{PiC}$ triggered reduction in mitochondrial ATP production, leading to attenuation of cytosolic $\mathrm{Ca}^{2+}$ oscillation and impaired glucosestimulated insulin secretion (GSIS) [62]. However, in insulin-secreting clonal cells (INS-1E), PiC suppression did not affect mitochondrial membrane potential, ATP production, and insulin secretion [4]. Further experiments are required to elucidate the contribution of different mitochondrial Pi transport systems to cellular metabolism and bioenergetics.

\subsection{DIC}

DIC is a mitochondrial integral membrane protein encoded by SLC25A10 in humans, which transports electroneutrally dicarboxylates such as malate, malonate, and succinate in exchange for phosphate, sulfate, and thiosulfate $[39,63]$. Notably, DIC is expressed most strongly in the liver, kidney, and white adipose tissue and at low levels in other tissues [64-66]. The reason behind the differential expression of DIC in various tissues is not clear, which may be related to the functions of those tissues. Remarkably, DIC expression is high in cancer tissues, which might be required for the regulation of oxidative stress and tumor growth. Furthermore, exposure to repetitive hypoxia upregulates DIC, which is involved in cancer cell survival and growth [67]. DIC facilitated not only dicarboxylate-Pi exchange but also exchange of dicarboxylate for dicarboxylate, which was proposed by Chappell and Haarhoff in 1966 [68]. Indeed, the principal function of DIC is to transport dicarboxylates from the cytoplasm into the mitochondria in exchange for Pi. However, along with 2-oxoglutarate carriers, it also catalyzes the uptake of glutathione (GSH) into the matrix by checking the effect of BMA, inhibiting $>80 \%$ of GSH efflux [69]. GSH is critical for numerous mitochondrial functions, including membrane structure and integrity, 
ion homeostasis, and mitochondrial redox status. These findings shed light on the role of DIC in mitochondria. DIC has been proposed to be essential for preserving redox control and normal respiration in rat brain mitochondria. DIC inhibition, resulting in depletion of the mitochondrial GSH pool, led to marked increase in mitochondrial ROS, followed by hyperpolarization of mitochondrial membrane potential and increase in basal respiration rates. Besides that, DIC suppression impaired complex I activity, but not those for complexes II and III [70]. Suppression of DIC expression in clonal insulin-secreting $832 / 13$ cells and isolated rat islets led to inhibition of GSIS by $5-69 \%$ [71].

Patients with heterozygous mutation in SLC25A10 showed severe neurodegenerative disorder, characterized by epileptic encephalopathy, complex I deficiency, and mitochondrial DNA depletion in skeletal muscle [72]. These phenotypes are not related to the functions of DIC, but to decrease in mitochondrial transport of reducing equivalents, anaplerotic Krebs cycle intermediates, or glutathione, which may lead to oxidative stress and mitochondrial dysfunction related to the symptoms observed.

\subsection{UCP2}

Uncoupling protein (UCP) family plays important roles in thermogenesis [73], obesity, diabetes [74], and oxidative stress-related diseases [75]. UCP1 was discovered firstly among members of this family, and UCP2 is a UCP1 ortholog also identified in mitochondria [76]. UCP2 is encoded by SLC25A8 gene and its mRNA was widely detected in a variety of tissues and cell types [77]. However, at protein level, UCP2 is mainly found in spleen, thymus, bone marrow, pancreas, stomach and lung [78,79]. It has been shown that UCP2 can bind fatty acids (FAs) laterally through its peripheral site, and this binding is critical for UCP2-catalyzed FA flipping across the membrane, which in turn is essential for proton exchange [80], however long-chain FAs are not the only activators of protein transport in $\mathrm{UCP} 2$. Additionally, $\mathrm{UCP} 2$ has been reported to catalyze the exchange of intramitochondrial $\mathrm{C}_{4}$ intermediates, such as malate, oxaloacetate, and aspartate, for cytosolic $\mathrm{Pi}$ via a $\mathrm{H}^{+}$ supported mechanism for Pi [41]. This electrogenic transport is driven by mitochondrial membrane potential (negative inside) and $\mathrm{pH}$ gradient (acidic outside) and is inhibited by the replacement of Gly-268 with Ala in UCP2 [41]. This study examined the physiological role of $\mathrm{UCP} 2$ by assessing the change in the levels of $\mathrm{C}_{4}$ intermediates, but not that of $\mathrm{Pi}$, as UCP2 might play a minor role in maintaining the mitochondrial Pi pool.

ROS or their byproducts is known to activate UCP2 [81]. Under oxidative stress condition, UCP2 induces proton leak of respiratory chain and decreases mitochondrial ROS production. Therefore, UCP2 can provide a negative feedback loop not to induce overproduction of mitochondrial superoxide. In addition, acute stimulation of UCP2 by ROS directly moderates the glutathionylation status of the UCP to decrease ROS production $[82,83]$. Mitochondrial ROS production is increased in UCP2 knockout mice, which disturbed mitochondrial dynamic balance towards fission and early damage to mitochondrial ultrastructures upon ischemic stress [84].

\section{4. $M g$-ATP/Pi Carrier}

Mitochondrial Mg-ATP/Pi carriers are encoded by SLC25A23, SLC25A24 and SLC25A25 [40], which transport Pi and adenine nucleotides including ATP, ATP- $\mathrm{Mg}^{2-}$, ADP, and AMP [85]. These carriers catalyze electroneutral exchange of divalent phosphate $\left(\mathrm{HPO}_{4}{ }^{2-}\right)$ with divalent ATP-Mg $\left(\mathrm{ATP}-\mathrm{Mg}^{2-}\right)$ or divalent protonated ADP $\left(\mathrm{H}-\mathrm{ADP}^{2-}\right)[40,86]$. Depending on the concentration gradients of adenine nucleotides and Pi across the inner mitochondrial membrane, $\mathrm{ATP}-\mathrm{Mg}^{2-}$ or $\mathrm{H}-\mathrm{ADP}^{2-}$ is incorporated and retained in the mitochondria. The $\mathrm{pH}$ gradient is the driving force for $\mathrm{Pi}$ accumulation via $\mathrm{PiC}$, which subsequently drives ATP- $\mathrm{Mg}^{2-}$ or $\mathrm{H}-\mathrm{ADP}^{2-}$ accumulation in the mitochondrial matrix. The same mechanism may hold for DIC, which facilitates the mitochondrial transport of malate or other dicarboxylates driven by the Pi gradient generated by PiC. Supporting evidence has shown that ATP- $\mathrm{Mg}^{2-}$ uptake or efflux depends on the $\mathrm{pH}$ gradient, which is abolished with nigericin and uncouplers [87]. 
An autosomal dominant mutation in SLC25A24 manifests as aged phenotypes with loose or wrinkled skin, short stature, hypertrichosis, skull deformities, and a characteristic facial appearance of a depressed nasal bridge, low hairline, and microphthalmia [88]. Interestingly, fibroblasts from patients with SLC25A24 mutation have altered mitochondrial morphology, decreased proliferation rate, oxygen consumption, and mitochondrial ATP content, whereas mitochondrial membrane potential and oxidative stress sensitivity are high $[89,90]$. These results indirectly indicated that the aged phenotypes associated with SLC25A24 mutations may be related to mitochondrial dysfunction and bioenergetic crisis, leading to imbalance in the proliferation and differentiation of progenitor cells of skeletal and connective tissues [52].

An essential characteristic of Mg-ATP/Pi carriers is that the transport of Pi and adenine nucleotides increases after activation by cytosolic $\mathrm{Ca}^{2+}$, as four $\mathrm{Ca}^{2+}$ binding EF-hand motifs are present on the $\mathrm{N}$-terminal regulatory domain located at the external face of the inner mitochondrial membrane [91,92]. This structure allows the mitochondria to convert cellular $\mathrm{Ca}^{2+}$ signals into activation of mitochondrial metabolism. Therefore, Mg-ATP/Pi carriers (SLC25A23-25) are classified as short $\mathrm{Ca}^{2+}$-binding mitochondrial carrier (SCaMCs), which contains SLC25A41 also [93].

It has been reported that SLC25A23, but not SLC25A24 and SLC25A25, promotes mitochondrial calcium uptake by interacting with the mitochondrial calcium uniporter (MCU) and MICU1 [94]. Genetic suppression of SLC25A23 decreased mitochondrial $\mathrm{Ca}^{2+}$ uptake and augmented agonist-stimulated cytosolic $\mathrm{Ca}^{2+}$ transients due to attenuated $\mathrm{Ca}^{2+}$ clearance. Furthermore, SLC25A23 silencing reduces basal mitochondrial ROS level, oxidant-induced ATP deterioration, and cell death [94]. Mitochondrial Pi transport is essentially critical for mediating mitochondrial $\mathrm{Ca}^{2+}$ signal, and conversely, $\mathrm{Ca}^{2+}$ regulates the activity of several mitochondrial Pi transporters. Hence, the close interplay between mitochondrial $\mathrm{Pi}$ and $\mathrm{Ca}^{2+}$ should be considered when analyzing cellular outcomes.

\subsection{Oxidative Stress Due to Mitochondrial Pi Transport}

Mitochondrial superoxide serves as the largest ROS reservoir in most cell types due to the dynamic activity of the electron transport chain. It is known that ROS production is highly intensified upon mitochondrial hyperpolarization and that only a small increase in the membrane potential can accelerate a large amount of ROS production in the mitochondria [95]. Pi is taken up into mitochondria through the above-described transporters, which may be electrogenic or electroneutral depending on the transport characteristics. Electroneutral transport also can modify mitochondrial membrane potential by altering electrochemical gradients and respiratory chain activity. Studies have shown that high extracellular Pi hyperpolarizes the mitochondrial membrane potential, which is followed by increase in mitochondrial ROS generation and cytotoxic detrimental changes [32,96]. Mitochondrial superoxide generation by high Pi was abolished by collapsing the mitochondrial membrane potential, indicating the critical role of hyperpolarization in ROS production [96].

As the main route of mitochondrial uptake, $\mathrm{Pi}$ transport via $\mathrm{PiC}$ is driven by the $\mathrm{pH}$ gradient across the inner mitochondrial membrane. This subsequently decreases the mitochondrial $\mathrm{pH}$ gradient, as $\mathrm{Pi}$ transport via $\mathrm{PiC}$ is coupled with $\mathrm{H}^{+}$uptake [4]. At the same time, the dissipation of the chemical $(\mathrm{pH})$ gradient can increase the electrical gradient (mitochondrial hyperpolarization) under the maintained proton motive force. Furthermore, Pi significantly accelerates oxidative phosphorylation by activating metabolic enzymes and respiratory chain activity, which additionally exalts the mitochondrial electrical gradient [97]. The further negative mitochondrial membrane potential augments superoxide generation from oxygen by binding with electrons that escaped from the ETC due to higher resistance of proton pumping against the established electrical gradient. This may partially explain how hyperpolarizing response via mitochondrial Pi transporters plays a substantial role in high Pi-induced oxidative stress.

In addition, ROS generation linked to the reverse electron transport (RET) also significantly contributes to the mitochondrial ROS pool. In general, an electron is transferred 
among respiratory complexes, which finally interacts with $\mathrm{O}_{2}$ to form $\mathrm{H}_{2} \mathrm{O}$. However, about $0.2-2 \%$ of the electrons in the ETC do not follow the normal transfer flow and instead directly leak out of the ETC, particularly from complexes I and III, and react with $\mathrm{O}_{2}$ to generate superoxide or hydrogen peroxide [98,99]. In this RET, the electrons do not move forward, but some from ubiquinol are transferred back to complex I, reducing $\mathrm{NAD}^{+}$to NADH [100]. A high ratio of ubiquinol to ubiquinone and a high proton motive force are critical for RET [101]. Both rotenone and FCCP remarkably decrease ROS generation via RET [102].

The amount of Pi transported into the mitochondria is remarkably altered by the cytosolic $\mathrm{pH}$; alkaline cytosolic condition increases mitochondrial Pi uptake [27]. Intriguingly, high extracellular Pi can alkalinize cytosolic and mitochondrial $\mathrm{pH}$, which may be related to the buffering action of $\mathrm{HPO}_{4}{ }^{2-} / \mathrm{H}_{2} \mathrm{PO}_{4}{ }^{-}$in the cytosol. Cytosolic alkalinization may accelerate mitochondrial Pi uptake, which augments mitochondrial superoxide generation [27]. Furthermore, cytosolic alkalinization stabilizes the semiquinone radical, a potential superoxide producer, consequently increasing the rate of free radical generation [103]. In addition, mitochondrial matrix alkalinization itself facilitates the opening of the mitochondrial PT pore, resulting in functional impairment [27]. With the Pi-induced changes in cytosolic and mitochondrial $\mathrm{pH}$, extracellular Pi can generate more oxidative stress in the mitochondria and aggravate pathogenic changes.

\section{Oxidative Stress Related to Cytosolic and Mitochondrial $\mathrm{Ca}^{2+}$ and Pi Overloads}

In the pathogenic process of vascular calcification, oxidative stress plays a critical role, which is related to upregulation of osteogenic genes and changes in calcification [104-106]. As described above, cellular Pi uptake via plasmalemmal and mitochondrial Pi transporters induces ROS generation in a high Pi environment in different types of cells, including VSMCs. Using cytosolic and/or mitochondrial antioxidants, suppression of oxidative stress has been shown to effectively attenuate Pi-induced vascular calcification [32,104]. Cellular $\mathrm{Ca}^{2+}$ and Pi synergistically act on the redox system, which later triggers ROS accumulation and oxidative stress. Intracellular $\mathrm{Ca}^{2+}$ is disturbed under high Pi conditions, which is associated with the development of many pathological changes. Notably, cellular uptake of Pi influences cytosolic and mitochondrial $\mathrm{Ca}^{2+}$ uptake and accumulation.

As described above, high Pi activates depolarization-triggered $\mathrm{Ca}^{2+}$ influx via VGCCs in VSMCs [32]. It has been proposed that high levels of Pi activate store-operated $\mathrm{Ca}^{2+}$ entry and impair $\mathrm{Ca}^{2+}$ efflux from the cytosol in VSMCs [107], leading to the accumulation of cytosolic and mitochondrial $\mathrm{Ca}^{2+}$. Interaction between $\mathrm{ROS}$ and $\mathrm{Ca}^{2+}$ is considered bidirectional, as $\mathrm{Ca}^{2+}$ is pivotal for ROS generation, while ROS can control cellular $\mathrm{Ca}^{2+}$ signaling [108]. As another consequence of the increase in $\left[\mathrm{Ca}^{2+}\right]_{i}$, the level of $\mathrm{Ca}^{2+}$ in the mitochondrial matrix increases due to more $\mathrm{Ca}^{2+}$ uptake from the cytosol. This elevation in matrix $\mathrm{Ca}^{2+}$ level stimulates the key mitochondrial enzymes of the tricarboxylic acid cycle, including pyruvate dehydrogenase, $\alpha$-ketoglutarate dehydrogenase, isocitrate dehydrogenase $[109,110]$, which in turn generate more $\mathrm{NADH}$ and $\mathrm{FADH}_{2}$ and induces excessive ETC activation, subsequently accelerating mitochondrial superoxide generation from ETCs. Moreover, $\mathrm{Ca}^{2+}$ activates ATP synthase (complex V) [111,112], $\alpha$-glycerophosphate dehydrogenase [113], and ANT [114], which enhance ETC activity. $\mathrm{Ca}^{2+}$ accumulation promotes oxidative stress by activating nitric oxide synthase (NOS), which blocks complex IV by synthesizing NO, leading to excess ROS formation [115-117]. Additionally, Pi reduces the expression of coenzyme $Q$, while maintenance of this coenzyme in an oxidized state counteracts $\mathrm{H}_{2} \mathrm{O}_{2}$ production and mitochondrial swelling [118].

Mitochondrial $\mathrm{Ca}^{2+}$ uptake via MCU is driven by an electrical gradient [119]; thus, ETC activation and hyperpolarization further augments mitochondrial $\mathrm{Ca}^{2+}$ uptake. This process is also accelerated by the presence of anions, such as $\mathrm{Pi}$, acetate, $\beta$-hydroxybutyrate, glutamate, and bicarbonate, which can provide a $\mathrm{H}^{+}$source for the $\mathrm{H}^{+}$pumps of the respiratory chain. In the absence of adequate $\mathrm{Pi}$, mitochondrial $\mathrm{Ca}^{2+}$ uptake, mitochondrial membrane potential, and $\mathrm{O}_{2}$ consumption rates are suppressed [120]. Moreover, mitochon- 
drial Pi assists in the formation of insoluble $\mathrm{Ca}^{2+}-\mathrm{Pi}$ salts in the matrix [121] and keeps the low level of ionized mitochondrial $\mathrm{Ca}^{2+}$, thereby maintaining active mitochondrial $\mathrm{Ca}^{2+} \mathrm{up}^{-}$ take by decreasing the uphill limitation of the $\mathrm{Ca}^{2+}$ gradient $[122,123]$. Thus, mitochondrial $\mathrm{Pi}$ uptake is possibly an important factor that regulates matrix $\mathrm{Ca}^{2+}$ levels and oxidative stress generation by prolonged $\mathrm{Ca}^{2+}$ and Pi overload.

Together with cytosolic $\mathrm{Ca}^{2+}$, the oxidative stress generated by excess Pi activates $\mathrm{ERK} / \mathrm{mTOR} / \mathrm{p} 70 \mathrm{~S} 6 \mathrm{~K}$ signaling. In turn, mTORC1 potentially suppresses the expression of antioxidant genes such as CAT, SOD1, and SOD2, causing an increase in oxidative stress [124,125]. It is noteworthy that superoxide production by high Pi was effectively inhibited by either decreasing extracellular $\mathrm{Ca}^{2+}$ concentration or by chelating intracellular $\mathrm{Ca}^{2+}$ [32]. Attenuation of cellular $\mathrm{Ca}^{2+}$ load using voltage-gated $\mathrm{Ca}^{2+}$ channel blockers also significantly alleviated ROS generation and calcific changes in VSMCs [32]. This indicates the close connection between cellular $\mathrm{Pi}$ and $\mathrm{Ca}^{2+}$ in oxidative stress-triggered vascular calcification (Figure 3).

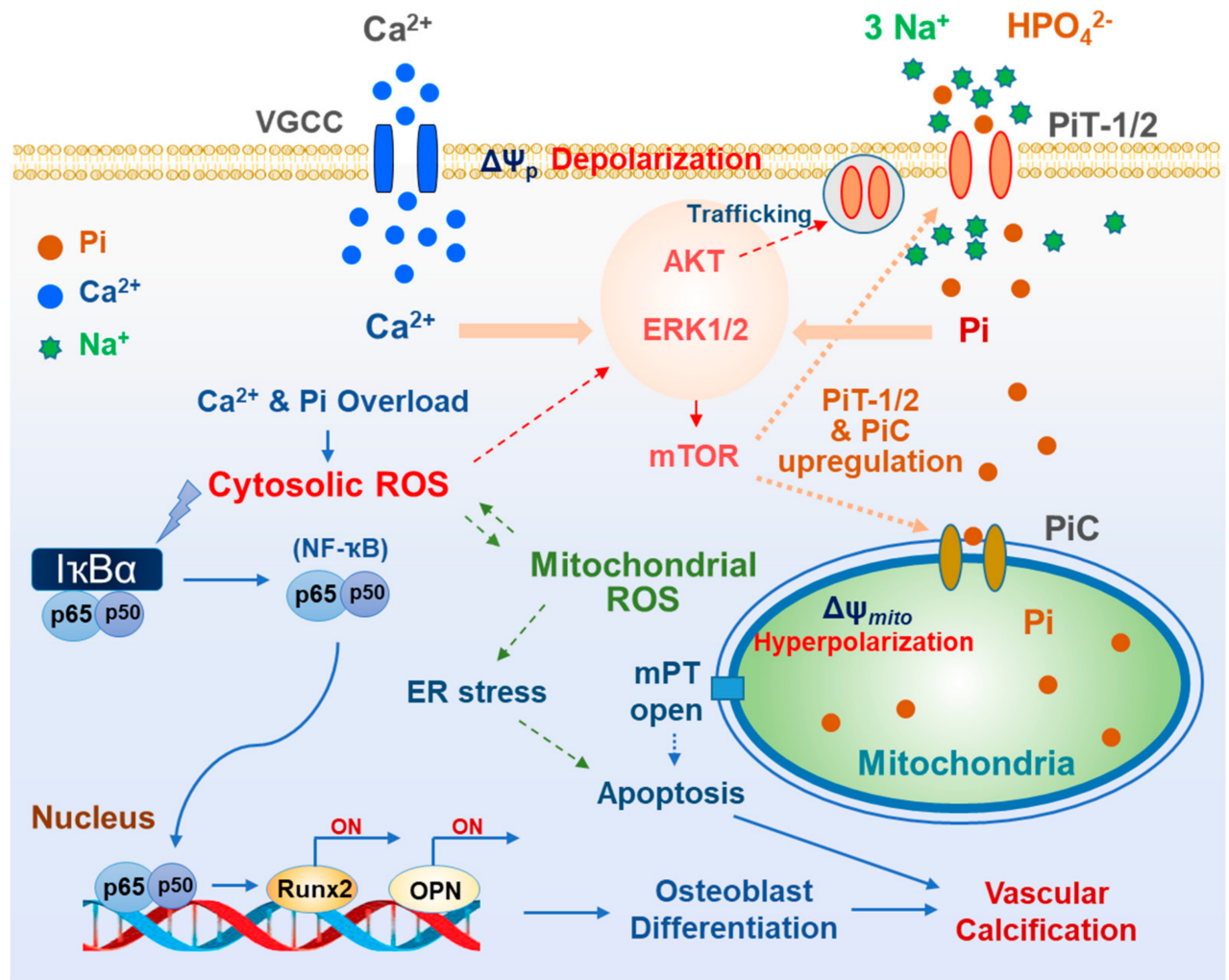

Figure 3. Oxidative stress related to plasmalemmal and mitochondrial Pi transporters in vascular calcification. Type III Na-Pi cotransporters, PiT-1 and PiT-2, can trigger plasma membrane depolarization due to their electrogenic properties. This depolarization couples cytosolic $\mathrm{Ca}^{2+}$ influx with $\mathrm{Pi}$, leading to more $\mathrm{Ca}^{2+}$ and Pi loading in cytosol. Suppressing the entrance of either $\mathrm{Ca}^{2+}$ or Pi successfully attenuate oxidative stress. In addition, Pi influx activates ERK and AKT signaling further augment PiT-1/-2 abundance either by translational regulation or by surface trafficking. Mitochondrial Pi transport, mainly mediated by $\mathrm{PiC}$, elicits mitochondrial hyperpolarization and superoxide generation. All these cytosolic and mitochondrial oxidative stress induces NF-B activation, osteogenic gene upregulation, ER stress and apoptosis leading to vascular calcification.

\section{Oxidative Stress and Vascular Medial Calcification}

VSMCs of different origins have been used to study the molecular mechanism underlying medial calcification, as they are in the majority in the medial layer of blood vessels. These cells are critical for the contraction and relaxation of blood vessels. Indeed, in most calcifying cell models, short- or long-term incubation with high Pi induces ROS production $[2,104,126]$. Regarding oxidative stress in calcification, increase in ROS generation is 
commonly detected in the blood vessels with vitamin D-induced aortic calcification and in rodents with 5/6 nephrectomy on high Pi diet [127-129]. In bovine aortic smooth muscle cells treated with $\beta$-glycerolphosphate, the mitochondrial ROS released into the cytosol promotes IKK $\beta$ phosphorylation, I $\kappa \mathrm{B} \alpha$ degradation, and NF- $\kappa \mathrm{B}$ nuclear translocation [126]. This NF- $\mathrm{KB}$ then acts in the nucleus as a transcription factor to upregulate osteogenic genes such as MSX2 and RUNX2, as well as its downstream ALP. Downregulation of endogenous NF- $\kappa B$ significantly decreases Pi-induced extracellular matrix calcification, suggesting the central role of NF- $\mathrm{B}$ signaling on vascular calcification [126]. Yoshida et al. also demonstrated the smooth muscle cell-selective suppression of NF- $\mathrm{kB}$ signaling or reduction in arterial medial calcification in mice with chronic kidney disease (CKD) fed high Pi diet after application of different NF-kB inhibitors [130].

MAPK signaling has been recognized as one of the central players in high Pi-induced calcification in VSMCs and in both human and animal calcification models. Treatment of mouse VSMCs with high Pi causes osteogenic/chondrogenic differentiation in conjunction with amplified phosphorylation of ERK1/2. Application of the MAPK inhibitor, UO126, or knockdown of plasma Pi transporters, PiT-1/-2, prevented the upregulation of RUNX2 upon incubation in the presence of high $\mathrm{Pi}[131,132]$. Indeed, mice with germline ablation of ERK1 and a conditional obstruction of ERK2 in limb mesenchyme (ERK1-/-ERK2Prx1 mice), including osteoblasts, exhibited considerably decreased bone mineralization, indicating the significance of ERK1/2 in osteoblast mineralization [133]. The downstream effects of ERK1/2 during vascular calcification are still not completely understood. However, further studies have shown that ERK1/2 modulates RUNX2 phosphorylation directly at four sites, S43, S301, S319 and S510, among which S301 and S319 contribute to RUNX2 transcriptional activity $[134,135]$. Recent studies have shown that ERK1/2 repression attenuates calcification by promoting the miR126-3p-DKK/LRP6 pathway [136,137]. This miRNA appears to play a protective role in vascular calcification $[138,139]$. Oxidative stress elicited by excess $\mathrm{Pi}$ is responsible for ERK1/2 activation, as Pi-induced ERK1/2 phosphorylation is abolished by lowering the levels of mitochondrial ROS [32].

The phosphoinositide 3-kinase (PI3K)/AKT pathway also contributes considerably to high Pi-induced increase in VSMC osteo-induction [140-142]. Whether activation or inhibition of AKT signaling triggers calcification is still not clear. Deng et al. suggested that AKT phosphorylation is highly critical for RUNX2 ubiquitination and its stabilization [140]. Cellular Pi uptake via PiT-1 was increased by plasma membrane trafficking of PiT-1 after PI3K/AKT activation [32]. In addition, upregulation of AKT/FOXO signaling has been observed in the vasculature of an aging rat model of atherosclerosis [143]. Cui et al. have shown that cell apoptosis and calcification is a result of PI3K/AKT inhibition in rat VSMCs [141]. In addition, FTI-277, a farnesyl transferase inhibitor, can suppress vascular calcification by upregulating PI3K/AKT signaling and preventing apoptosis [142]. A recent study showed that miR155 deficiency attenuated, whereas miR155 overexpression induced by high levels of $\mathrm{Ca}^{2+}$ and Pi enhanced vascular calcification by regulating AKT activation and FOXO3a degradation [144]. Indeed, mitochondrial ROS aggravates PTEN oxidative inactivation, which is crucial for inducing PI3K/AKT/mTOR signaling [145].

A recent work has been shown that ER stress intensified the calcification of VSMCs by stimulating the release of Grp78-loaded extracellular vesicles [146]. Additionally, activated mTORC1 potentiates ER stress, resulting in diminished production of an endogenous inhibitor of mineralization and osteoblastic trans-differentiation of VSMCs in CKD mice [147]. It is noteworthy that mitochondria and ER have a tight connection, because of which mitochondrial dysfunction induces ER stress and vice versa [148]. Indeed, high Pi level promotes mitochondrial ROS production in insulin-secreting cells, eliciting ER stress and apoptosis, which were prevented by a mitochondrial superoxide scavenger [96]. Vascular calcification is accompanied by upregulation of ER stress markers, including GRP78, GRP94 and CHOP, and consequent apoptosis in VSMCs [149]. The PERK-eIF2 $\alpha$-ATF4-CHOP complex is formed as a part of the integrated stress response and it is upregulated in animal models of vascular calcification $[150,151]$. In human VSMCs, oxidative stress induces ER 
stress via the IRE-1-XBP1-GRP78 pathway. In particular, XBP-1, upregulated by ER stress, can bind to the RUNX2 promoter, eliciting VSMC differentiation and calcification [152]. More clarification regarding the connection between mitochondrial ROS and ER stress is required to understand the mechanism underlying progression of vascular calcification.

\section{Conclusions}

As described above, regulation of Pi uptake via plasmalemmal and mitochondrial $\mathrm{Pi}$ transporters is related to the pathophysiology of oxidative stress-induced vascular calcification. Plasmalemmal Pi transport can induce cytosolic $\mathrm{Ca}^{2+}$ accumulation due to depolarization-activated $\mathrm{Ca}^{2+}$ influx. Mitochondrial Pi transport also increases net $\mathrm{Ca}^{2+}$ uptake due to augmented electrical driving force and free $\mathrm{Ca}^{2+}$ gradients. Oxidative stress due to $\mathrm{Ca}^{2+}$ and Pi overload induces mitochondrial dysfunction, ER stress, and lysosomal dysfunction, all of which are caused or aggravated by perturbations in $\mathrm{Ca}^{2+}$ homeostasis (Figure 4). Excessive intracellular and intramitochondrial $\mathrm{Ca}^{2+}$ and $\mathrm{Pi}$ synergistically increase the levels of cytosolic and mitochondrial ROS. Thus, suppressing either $\mathrm{Ca}^{2+}$ or $\mathrm{Pi}$ overload may abrogate pathological oxidative stress and disease progression.

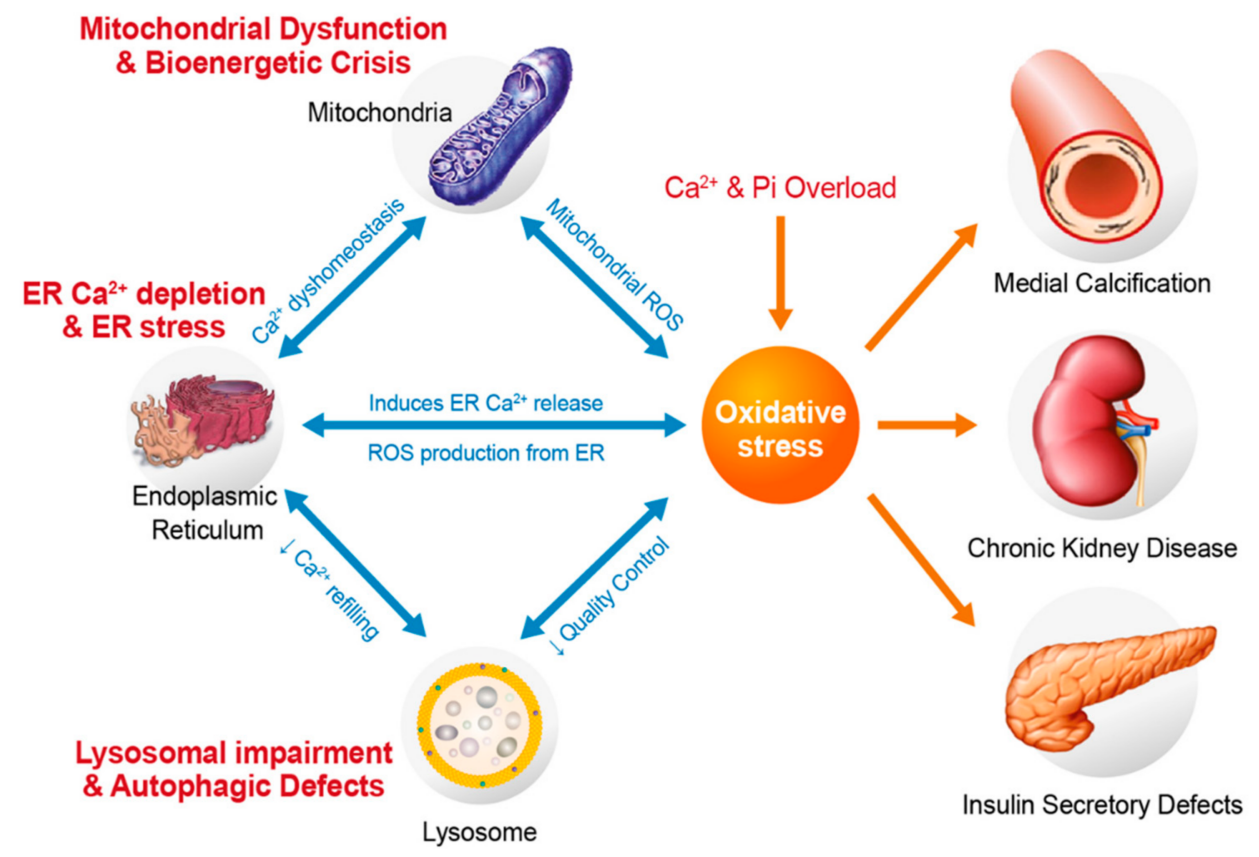

Figure 4. Oxidative stress by $\mathrm{Ca}$ and Pi overloads in vascular calcification. Ca and Pi overloads accelerates cytosolic and mitochondrial oxidative stress, which can induce more mitochondrial dysfunction and ER stress. Depletion of the ER Ca pool further increases ROS generation from mitochondrial and the ER, which also disturbs lysosomal Ca homeostasis and autophagy defects. All these pathologic alterations in organelles aggravate oxidative stress and disease progression including arterial medial calcification.

It is noteworthy that elevated Pi levels initiate a positive feedback activation loop, establishing a vicious cycle of Pi toxicity. Pi uptake mediated by PiT-1 increases the abundance of functional PiT-1 by translational upregulation and surface trafficking. Our recent unpublished data showed that high Pi treatment increased the abundance of mitochondrial $\mathrm{PiC}$ in an ERK1/2-mTOR-dependent manner (data not shown). Cytosolic alkalinization due to Pi uptake also accelerates mitochondrial Pi influx and facilitates PT pore opening. All these mechanisms amplify Pi overload-induced detrimental changes in the cytosol and mitochondria after oxidative stress. On the contrary, this positive feedback mechanism might prevent disease progression by inhibiting any one component of the signal amplification loop. Further investigations to elucidate the mechanism via which Pi accumulates 
with $\mathrm{Ca}^{2+}$ and generates oxidative stress, and its pathological consequences, may reveal a novel therapeutic strategy against vascular calcification.

Author Contributions: Conceptualization, N.T.N., T.T.N. and K.-S.P.; writing-original draft preparation, N.T.N., T.T.N. and K.-S.P.; writing-review and editing, N.T.N., T.T.N. and K.-S.P.; funding acquisition, K.-S.P. All authors have read and agreed to the published version of the manuscript.

Funding: This work was supported by the Medical Research Center Program (2017R1A5A2015369) from the Ministry of Science, ICT, Korea.

Acknowledgments: We appreciate the kind help from Myung Ha Kim for the preparation of this manuscript.

Conflicts of Interest: The authors declare no conflict of interest.

\section{References}

1. Yamamoto, Y.; Ishikawa, Y.; Shimpo, M.; Matsumura, M. Mönckeberg's sclerosis. J. Gen. Fam. Med. 2021, 22, 55-56. [CrossRef] [PubMed]

2. Lee, S.J.; Lee, I.K.; Jeon, J.H. Vascular calcification-new insights into its mechanism. Int. J. Mol. Sci. 2020, 21, 2685. [CrossRef] [PubMed]

3. Ho, C.Y.; Shanahan, C.M. Medial arterial calcification: An overlooked player in peripheral arterial disease. Arterioscler. Thromb. Vasc. Biol. 2016, 36, 1475-1482. [CrossRef] [PubMed]

4. Quan, X.; Das, R.; Xu, S.; Cline, G.W.; Wiederkehr, A.; Wollheim, C.B.; Park, K.S. Mitochondrial phosphate transport during nutrient stimulation of ins-1e insulinoma cells. Mol. Cell. Endocrinol. 2013, 381, 198-209. [CrossRef] [PubMed]

5. Biber, J.; Hernando, N.; Forster, I. Phosphate transporters and their function. Annu. Rev. Physiol. 2013, 75, 535-550. [CrossRef]

6. Forster, I.C.; Hernando, N.; Biber, J.; Murer, H. Phosphate transporters of the slc20 and slc34 families. Mol. Asp. Med. 2013, 34, 386-395. [CrossRef]

7. Wagner, C.A.; Hernando, N.; Forster, I.C.; Biber, J. The slc34 family of sodium-dependent phosphate transporters. Pflugers Arch. 2014, 466, 139-153. [CrossRef]

8. Forster, I.C.; Hernando, N.; Biber, J.; Murer, H. Phosphate transport kinetics and structure-function relationships of slc34 and slc20 proteins. Curr. Top. Membr. 2012, 70, 313-356. [CrossRef]

9. Miyamoto, K.; Haito-Sugino, S.; Kuwahara, S.; Ohi, A.; Nomura, K.; Ito, M.; Kuwahata, M.; Kido, S.; Tatsumi, S.; Kaneko, I.; et al. Sodium-dependent phosphate cotransporters: Lessons from gene knockout and mutation studies. J. Pharm. Sci. 2011, 100, 3719-3730. [CrossRef]

10. Breusegem, S.Y.; Takahashi, H.; Giral-Arnal, H.; Wang, X.; Jiang, T.; Verlander, J.W.; Wilson, P.; Miyazaki-Anzai, S.; Sutherland, E.; Caldas, Y.; et al. Differential regulation of the renal sodium-phosphate cotransporters napi-iia, napi-iic, and pit-2 in dietary potassium deficiency. Am. J. Physiol. Renal Physiol. 2009, 297, F350-F361. [CrossRef]

11. Ghezzi, C.; Meinild, A.K.; Murer, H.; Forster, I.C. Voltage- and substrate-dependent interactions between sites in putative re-entrant domains of a $\mathrm{Na}(+)$-coupled phosphate cotransporter. Pflugers Arch. 2011, 461, 645-663. [CrossRef] [PubMed]

12. Moschèn, I.; Setiawan, I.; Bröer, S.; Murer, H.; Lang, F. Effect of napi-mediated phosphate transport on intracellular ph. Pflugers Arch. 2001, 441, 802-806. [CrossRef]

13. Segawa, H.; Aranami, F.; Kaneko, I.; Tomoe, Y.; Miyamoto, K. The roles of na/pi-ii transporters in phosphate metabolism. Bone 2009, 45 (Suppl. S1), S2-S7. [CrossRef] [PubMed]

14. Segawa, H.; Onitsuka, A.; Furutani, J.; Kaneko, I.; Aranami, F.; Matsumoto, N.; Tomoe, Y.; Kuwahata, M.; Ito, M.; Matsumoto, M.; et al. Npt2a and npt2c in mice play distinct and synergistic roles in inorganic phosphate metabolism and skeletal development. Am. J. Physiol. Renal Physiol. 2009, 297, F671-F678. [CrossRef] [PubMed]

15. Li, X.; Yang, H.Y.; Giachelli, C.M. Role of the sodium-dependent phosphate cotransporter, pit-1, in vascular smooth muscle cell calcification. Circ. Res. 2006, 98, 905-912. [CrossRef]

16. Villa-Bellosta, R.; Bogaert, Y.E.; Levi, M.; Sorribas, V. Characterization of phosphate transport in rat vascular smooth muscle cells: Implications for vascular calcification. Arterioscler. Thromb. Vasc. Biol. 2007, 27, 1030-1036. [CrossRef] [PubMed]

17. Voelkl, J.; Alesutan, I.; Leibrock, C.B.; Quintanilla-Martinez, L.; Kuhn, V.; Feger, M.; Mia, S.; Ahmed, M.S.; Rosenblatt, K.P.; Kuro, O.M.; et al. Spironolactone ameliorates pit1-dependent vascular osteoinduction in klotho-hypomorphic mice. J. Clin. Investig. 2013, 123, 812-822. [CrossRef]

18. Sekiguchi, S.; Suzuki, A.; Asano, S.; Nishiwaki-Yasuda, K.; Shibata, M.; Nagao, S.; Yamamoto, N.; Matsuyama, M.; Sato, Y.; Yan, K.; et al. Phosphate overload induces podocyte injury via type iii na-dependent phosphate transporter. Am. J. Physiol. Renal Physiol. 2011, 300, F848-F856. [CrossRef]

19. Werner, A.; Dehmelt, L.; Nalbant, P. Na+-dependent phosphate cotransporters: The napi protein families. J. Exp. Biol. 1998, 201,3135-3142. [CrossRef] 
20. Bergwitz, C.; Roslin, N.M.; Tieder, M.; Loredo-Osti, J.C.; Bastepe, M.; Abu-Zahra, H.; Frappier, D.; Burkett, K.; Carpenter, T.O.; Anderson, D.; et al. Slc34a3 mutations in patients with hereditary hypophosphatemic rickets with hypercalciuria predict a key role for the sodium-phosphate cotransporter napi-iic in maintaining phosphate homeostasis. Am. J. Hum. Genet. 2006, 78, 179-192. [CrossRef]

21. Gonzalez-Parra, E.; Tuñón, J.; Egido, J.; Ortiz, A. Phosphate: A stealthier killer than previously thought? Cardiovasc. Pathol. 2012, 21,372-381. [CrossRef] [PubMed]

22. Ohi, A.; Hanabusa, E.; Ueda, O.; Segawa, H.; Horiba, N.; Kaneko, I.; Kuwahara, S.; Mukai, T.; Sasaki, S.; Tominaga, R.; et al. Inorganic phosphate homeostasis in sodium-dependent phosphate cotransporter npt $2 \mathrm{~b}^{+/-}$mice. Am. J. Physiol. Renal Physiol. 2011, 301, F1105-F1113. [CrossRef] [PubMed]

23. Miller, D.G.; Edwards, R.H.; Miller, A.D. Cloning of the cellular receptor for amphotropic murine retroviruses reveals homology to that for gibbon ape leukemia virus. Proc. Natl. Acad. Sci. USA 1994, 91, 78-82. [CrossRef] [PubMed]

24. O'Hara, B.; Johann, S.V.; Klinger, H.P.; Blair, D.G.; Rubinson, H.; Dunn, K.J.; Sass, P.; Vitek, S.M.; Robins, T. Characterization of a human gene conferring sensitivity to infection by gibbon ape leukemia virus. Cell Growth Differ. 1990, 1, 119-127.

25. Kavanaugh, M.P.; Miller, D.G.; Zhang, W.; Law, W.; Kozak, S.L.; Kabat, D.; Miller, A.D. Cell-surface receptors for gibbon ape leukemia virus and amphotropic murine retrovirus are inducible sodium-dependent phosphate symporters. Proc. Natl. Acad. Sci. USA 1994, 91, 7071-7075. [CrossRef]

26. Olah, Z.; Lehel, C.; Anderson, W.B.; Eiden, M.V.; Wilson, C.A. The cellular receptor for gibbon ape leukemia virus is a novel high affinity sodium-dependent phosphate transporter. J. Biol. Chem. 1994, 269, 25426-25431. [CrossRef]

27. Nguyen, T.T.; Quan, X.; Xu, S.; Das, R.; Cha, S.K.; Kong, I.D.; Shong, M.; Wollheim, C.B.; Park, K.S. Intracellular alkalinization by phosphate uptake via type iii sodium-phosphate cotransporter participates in high-phosphate-induced mitochondrial oxidative stress and defective insulin secretion. FASEB J. 2016, 30, 3979-3988. [CrossRef]

28. Beck, L.; Leroy, C.; Beck-Cormier, S.; Forand, A.; Salaün, C.; Paris, N.; Bernier, A.; Ureña-Torres, P.; Prié, D.; Ollero, M.; et al. The phosphate transporter pit1 (slc20a1) revealed as a new essential gene for mouse liver development. PLoS ONE 2010, 5, e9148. [CrossRef]

29. Jensen, N.; Schrøder, H.D.; Hejbøl, E.K.; Füchtbauer, E.M.; de Oliveira, J.R.; Pedersen, L. Loss of function of slc20a2 associated with familial idiopathic basal ganglia calcification in humans causes brain calcifications in mice. J. Mol. Neurosci. 2013, 51,994-999. [CrossRef]

30. Ren, Y.; Shen, Y.; Si, N.; Fan, S.; Zhang, Y.; Xu, W.; Shi, L.; Zhang, X. Slc20a2-deficient mice exhibit multisystem abnormalities and impaired spatial learning memory and sensorimotor gating but normal motor coordination abilities. Front. Genet. 2021, 12, 639935. [CrossRef]

31. Crouthamel, M.H.; Lau, W.L.; Leaf, E.M.; Chavkin, N.W.; Wallingford, M.C.; Peterson, D.F.; Li, X.; Liu, Y.; Chin, M.T.; Levi, M.; et al. Sodium-dependent phosphate cotransporters and phosphate-induced calcification of vascular smooth muscle cells: Redundant roles for pit-1 and pit-2. Arterioscler. Thromb. Vasc. Biol. 2013, 33, 2625-2632. [CrossRef] [PubMed]

32. Nguyen, N.T.; Nguyen, T.T.; Ly, D.D.; Xia, J.-B.; Qi, X.-F.; Lee, I.-K.; Cha, S.-K.; Park, K.-S. Oxidative stress by Ca ${ }^{2+}$ overload is critical for phosphate-induced vascular calcification. Am. J. Physiol. -Heart Circ. Physiol. 2020, 319, H1302-H1312. [CrossRef] [PubMed]

33. Yamada, S.; Leaf, E.M.; Chia, J.J.; Cox, T.C.; Speer, M.Y.; Giachelli, C.M. Pit-2, a type iii sodium-dependent phosphate transporter, protects against vascular calcification in mice with chronic kidney disease fed a high-phosphate diet. Kidney Int. 2018, 94, 716-727. [CrossRef] [PubMed]

34. Chen, W.C.; Li, Q.L.; Pan, Q.; Zhang, H.Y.; Fu, X.Y.; Yao, F.; Wang, J.N.; Yang, A.K. Xenotropic and polytropic retrovirus receptor 1 (xpr1) promotes progression of tongue squamous cell carcinoma (tscc) via activation of nf-kb signaling. J. Exp. Clin. Cancer Res. 2019, 38, 167. [CrossRef] [PubMed]

35. Secco, D.; Wang, C.; Arpat, B.A.; Wang, Z.; Poirier, Y.; Tyerman, S.D.; Wu, P.; Shou, H.; Whelan, J. The emerging importance of the spx domain-containing proteins in phosphate homeostasis. New Phytol. 2012, 193, 842-851. [CrossRef] [PubMed]

36. Legati, A.; Giovannini, D.; Nicolas, G.; López-Sánchez, U.; Quintáns, B.; Oliveira, J.R.; Sears, R.L.; Ramos, E.M.; Spiteri, E.; Sobrido, M.J.; et al. Mutations in xpr1 cause primary familial brain calcification associated with altered phosphate export. Nat. Genet. 2015, 47, 579-581. [CrossRef]

37. Ansermet, C.; Moor, M.B.; Centeno, G.; Auberson, M.; Hu, D.Z.; Baron, R.; Nikolaeva, S.; Haenzi, B.; Katanaeva, N.; Gautschi, I.; et al. Renal fanconi syndrome and hypophosphatemic rickets in the absence of xenotropic and polytropic retroviral receptor in the nephron. J. Am. Soc. Nephrol. 2017, 28, 1073-1078. [CrossRef]

38. Krämer, R. Structural and functional aspects of the phosphate carrier from mitochondria. Kidney Int. 1996, 49, 947-952. [CrossRef]

39. Palmieri, L.; Palmieri, F.; Runswick, M.J.; Walker, J.E. Identification by bacterial expression and functional reconstitution of the yeast genomic sequence encoding the mitochondrial dicarboxylate carrier protein. FEBS Lett. 1996, 399, 299-302. [CrossRef]

40. Fiermonte, G.; De Leonardis, F.; Todisco, S.; Palmieri, L.; Lasorsa, F.M.; Palmieri, F. Identification of the mitochondrial atp$\mathrm{mg} /$ pi transporter. Bacterial expression, reconstitution, functional characterization, and tissue distribution. J. Biol. Chem. 2004, 279, 30722-30730. [CrossRef]

41. Vozza, A.; Parisi, G.; De Leonardis, F.; Lasorsa, F.M.; Castegna, A.; Amorese, D.; Marmo, R.; Calcagnile, V.M.; Palmieri, L.; Ricquier, D.; et al. Ucp2 transports c4 metabolites out of mitochondria, regulating glucose and glutamine oxidation. Proc. Natl. Acad. Sci. USA 2014, 111, 960-965. [CrossRef] [PubMed] 
42. Palmieri, F. The mitochondrial transporter family slc25: Identification, properties and physiopathology. Mol. Asp. Med. 2013, 34, 465-484. [CrossRef] [PubMed]

43. Runswick, M.J.; Powell, S.J.; Nyren, P.; Walker, J.E. Sequence of the bovine mitochondrial phosphate carrier protein: Structural relationship to adp/atp translocase and the brown fat mitochondria uncoupling protein. EMBO J. 1987, 6, 1367-1373. [CrossRef] [PubMed]

44. Dolce, V.; Fiermonte, G.; Palmieri, F. Tissue-specific expression of the two isoforms of the mitochondrial phosphate carrier in bovine tissues. FEBS Lett. 1996, 399, 95-98. [CrossRef]

45. Palmieri, F.; Bisaccia, F.; Capobianco, L.; Dolce, V.; Fiermonte, G.; Iacobazzi, V.; Zara, V. Transmembrane topology, genes, and biogenesis of the mitochondrial phosphate and oxoglutarate carriers. J. Bioenerg. Biomembr. 1993, 25, 493-501. [CrossRef]

46. Dolce, V.; Iacobazzi, V.; Palmieri, F.; Walker, J.E. The sequences of human and bovine genes of the phosphate carrier from mitochondria contain evidence of alternatively spliced forms. J. Biol. Chem. 1994, 269, 10451-10460. [CrossRef]

47. Boulet, A.; Vest, K.E.; Maynard, M.K.; Gammon, M.G.; Russell, A.C.; Mathews, A.T.; Cole, S.E.; Zhu, X.; Phillips, C.B.; Kwong, J.Q.; et al. The mammalian phosphate carrier slc25a3 is a mitochondrial copper transporter required for cytochrome $\mathrm{C}$ oxidase biogenesis. J. Biol. Chem. 2018, 293, 1887-1896. [CrossRef]

48. Fonyó, A.; Ligeti, E. The role of intramitochondrial pi in stimulation of respiration by calcium and strontium. FEBS Lett. 1978, 93, 289-292. [CrossRef]

49. Gutiérrez-Aguilar, M.; Douglas, D.L.; Gibson, A.K.; Domeier, T.L.; Molkentin, J.D.; Baines, C.P. Genetic manipulation of the cardiac mitochondrial phosphate carrier does not affect permeability transition. J. Mol. Cell. Cardiol. 2014, 72, 316-325. [CrossRef]

50. Kwong, J.; Davis, J.; Baines, C.; Sargent, M.; Karch, J.; Wang, X.; Huang, T.; Molkentin, J. Genetic deletion of the mitochondrial phosphate carrier desensitizes the mitochondrial permeability transition pore and causes cardiomyopathy. Cell Death Differ. 2014, 21, 1209-1217. [CrossRef]

51. Seifert, E.L.; Ligeti, E.; Mayr, J.A.; Sondheimer, N.; Hajnóczky, G. The mitochondrial phosphate carrier: Role in oxidative metabolism, calcium handling and mitochondrial disease. Biochem. Biophys. Res. Commun. 2015, 464, 369-375. [CrossRef] [PubMed]

52. Palmieri, F.; Scarcia, P.; Monné, M. Diseases caused by mutations in mitochondrial carrier genes slc25: A review. Biomolecules 2020, 10, 655. [CrossRef] [PubMed]

53. Mayr, J.A.; Merkel, O.; Kohlwein, S.D.; Gebhardt, B.R.; Böhles, H.; Fötschl, U.; Koch, J.; Jaksch, M.; Lochmüller, H.; Horváth, R.; et al. Mitochondrial phosphate-carrier deficiency: A novel disorder of oxidative phosphorylation. Am. J. Hum. Genet. 2007, 80, 478-484. [CrossRef]

54. Mayr, J.A.; Zimmermann, F.A.; Horváth, R.; Schneider, H.-C.; Schoser, B.; Holinski-Feder, E.; Czermin, B.; Freisinger, P.; Sperl, W. Deficiency of the mitochondrial phosphate carrier presenting as myopathy and cardiomyopathy in a family with three affected children. Neuromuscul. Disord. 2011, 21, 803-808. [CrossRef] [PubMed]

55. Zorov, D.B.; Juhaszova, M.; Yaniv, Y.; Nuss, H.B.; Wang, S.; Sollott, S.J. Regulation and pharmacology of the mitochondrial permeability transition pore. Cardiovasc. Res. 2009, 83, 213-225. [CrossRef] [PubMed]

56. Leung, A.W.; Varanyuwatana, P.; Halestrap, A.P. The mitochondrial phosphate carrier interacts with cyclophilin d and may play a key role in the permeability transition. J. Biol. Chem. 2008, 283, 26312-26323. [CrossRef]

57. Varanyuwatana, P.; Halestrap, A.P. The roles of phosphate and the phosphate carrier in the mitochondrial permeability transition pore. Mitochondrion 2012, 12, 120-125. [CrossRef]

58. Basso, E.; Petronilli, V.; Forte, M.A.; Bernardi, P. Phosphate is essential for inhibition of the mitochondrial permeability transition pore by cyclosporin a and by cyclophilin d ablation. J. Biol. Chem. 2008, 283, 26307-26311. [CrossRef]

59. Poncet, D.; Pauleau, A.L.; Szabadkai, G.; Vozza, A.; Scholz, S.R.; Le Bras, M.; Brière, J.J.; Jalil, A.; Le Moigne, R.; Brenner, C.; et al. Cytopathic effects of the cytomegalovirus-encoded apoptosis inhibitory protein vmia. J. Cell Biol. 2006, 174, 985-996. [CrossRef]

60. Poncet, D.; Larochette, N.; Pauleau, A.L.; Boya, P.; Jalil, A.A.; Cartron, P.F.; Vallette, F.; Schnebelen, C.; Bartle, L.M.; Skaletskaya, A.; et al. An anti-apoptotic viral protein that recruits bax to mitochondria. J. Biol. Chem. 2004, 279, 22605-22614. [CrossRef]

61. Pauleau, A.L.; Galluzzi, L.; Scholz, S.R.; Larochette, N.; Kepp, O.; Kroemer, G. Unexpected role of the phosphate carrier in mitochondrial fragmentation. Cell Death Differ. 2008, 15, 616-618. [CrossRef]

62. Nishi, Y.; Fujimoto, S.; Sasaki, M.; Mukai, E.; Sato, H.; Sato, Y.; Tahara, Y.; Nakamura, Y.; Inagaki, N. Role of mitochondrial phosphate carrier in metabolism-secretion coupling in rat insulinoma cell line ins-1. Biochem. J. 2011, 435, 421-430. [CrossRef] [PubMed]

63. Palmieri, F. Mitochondrial carrier proteins. FEBS Lett. 1994, 346, 48-54. [CrossRef]

64. Das, K.; Lewis, R.Y.; Combatsiaris, T.P.; Lin, Y.; Shapiro, L.; Charron, M.J.; Scherer, P.E. Predominant expression of the mitochondrial dicarboxylate carrier in white adipose tissue. Biochem. J. 1999, 344 Pt 2, 313-320. [CrossRef]

65. Fiermonte, G.; Dolce, V.; Arrigoni, R.; Runswick, M.J.; Walker, J.E.; Palmieri, F. Organization and sequence of the gene for the human mitochondrial dicarboxylate carrier: Evolution of the carrier family. Biochem. J. 1999, 344 Pt 3, 953-960. [CrossRef] [PubMed]

66. Coty, W.A.; Pedersen, P.L. Phosphate transport in rat liver mitochondria. Kinetics and energy requirements. J. Biol. Chem. 1974, 249, 2593-2598. [CrossRef] 
67. Hlouschek, J.; Ritter, V.; Wirsdörfer, F.; Klein, D.; Jendrossek, V.; Matschke, J. Targeting slc25a10 alleviates improved antioxidant capacity and associated radioresistance of cancer cells induced by chronic-cycling hypoxia. Cancer Lett. 2018, 439, 24-38. [CrossRef] [PubMed]

68. Johnson, R.N.; Chappell, J.B. The transport of inorganic phosphate by the mitochondrial dicarboxylate carrier. Biochem. J. 1973, 134, 769-774. [CrossRef]

69. Chen, Z.; Lash, L.H. Evidence for mitochondrial uptake of glutathione by dicarboxylate and 2-oxoglutarate carriers. J. Pharmacol. Exp. Ther. 1998, 285, 608-618.

70. Kamga, C.K.; Zhang, S.X.; Wang, Y. Dicarboxylate carrier-mediated glutathione transport is essential for reactive oxygen species homeostasis and normal respiration in rat brain mitochondria. Am. J. Physiol. Cell Physiol. 2010, 299, C497-C505. [CrossRef]

71. Huypens, P.; Pillai, R.; Sheinin, T.; Schaefer, S.; Huang, M.; Odegaard, M.L.; Ronnebaum, S.M.; Wettig, S.D.; Joseph, J.W. The dicarboxylate carrier plays a role in mitochondrial malate transport and in the regulation of glucose-stimulated insulin secretion from rat pancreatic beta cells. Diabetologia 2011, 54, 135-145. [CrossRef] [PubMed]

72. Punzi, G.; Porcelli, V.; Ruggiu, M.; Hossain, M.F.; Menga, A.; Scarcia, P.; Castegna, A.; Gorgoglione, R.; Pierri, C.L.; Laera, L. Slc25a10 biallelic mutations in intractable epileptic encephalopathy with complex i deficiency. Hum. Mol. Genet. 2018, 27, 499-504. [CrossRef] [PubMed]

73. Enerbäck, S.; Jacobsson, A.; Simpson, E.M.; Guerra, C.; Yamashita, H.; Harper, M.E.; Kozak, L.P. Mice lacking mitochondrial uncoupling protein are cold-sensitive but not obese. Nature 1997, 387, 90-94. [CrossRef] [PubMed]

74. Zhang, C.-Y.; Baffy, G.; Perret, P.; Krauss, S.; Peroni, O.; Grujic, D.; Hagen, T.; Vidal-Puig, A.J.; Boss, O.; Kim, Y.-B.; et al. Uncoupling protein-2 negatively regulates insulin secretion and is a major link between obesity, $\beta$ cell dysfunction, and type 2 diabetes. Cell 2001, 105, 745-755. [CrossRef]

75. Tian, X.Y.; Ma, S.; Tse, G.; Wong, W.T.; Huang, Y. Uncoupling protein 2 in cardiovascular health and disease. Front. Physiol. 2018, 9, 1060. [CrossRef]

76. Fleury, C.; Neverova, M.; Collins, S.; Raimbault, S.; Champigny, O.; Levi-Meyrueis, C.; Bouillaud, F.; Seldin, M.F.; Surwit, R.S.; Ricquier, D.; et al. Uncoupling protein-2: A novel gene linked to obesity and hyperinsulinemia. Nat. Genet. 1997, 15, $269-272$. [CrossRef] [PubMed]

77. Langin, D.; Larrouy, D.; Barbe, P.; Millet, L.; Viguerie-Bascands, N.; Andreelli, F.; Laville, M.; Vidal, H. Uncoupling protein-2 (ucp2) and uncoupling protein-3 (ucp3) expression in adipose tissue and skeletal muscle in humans. Int. J. Obes. Relat. Metab. Disord. 1999, 23 (Suppl. S6), S64-S67. [CrossRef]

78. Rupprecht, A.; Bräuer, A.U.; Smorodchenko, A.; Goyn, J.; Hilse, K.E.; Shabalina, I.G.; Infante-Duarte, C.; Pohl, E.E. Quantification of uncoupling protein 2 reveals its main expression in immune cells and selective up-regulation during t-cell proliferation. PLoS ONE 2012, 7, e41406. [CrossRef]

79. Pecqueur, C.; Alves-Guerra, M.C.; Gelly, C.; Levi-Meyrueis, C.; Couplan, E.; Collins, S.; Ricquier, D.; Bouillaud, F.; Miroux, B. Uncoupling protein 2, in vivo distribution, induction upon oxidative stress, and evidence for translational regulation. J. Biol. Chem. 2001, 276, 8705-8712. [CrossRef]

80. Berardi, M.J.; Chou, J.J. Fatty acid flippase activity of ucp2 is essential for its proton transport in mitochondria. Cell. Metab. 2014, 20, 541-552. [CrossRef]

81. Echtay, K.S.; Roussel, D.; St-Pierre, J.; Jekabsons, M.B.; Cadenas, S.; Stuart, J.A.; Harper, J.A.; Roebuck, S.J.; Morrison, A.; Pickering, S.; et al. Superoxide activates mitochondrial uncoupling proteins. Nature 2002, 415, 96-99. [CrossRef] [PubMed]

82. Chen, W.; Luo, S.; Xie, P.; Hou, T.; Yu, T.; Fu, X. Overexpressed ucp2 regulates mitochondrial flashes and reverses lipopolysaccharide-induced cardiomyocytes injury. Am. J. Transl. Res. 2018, 10, 1347-1356. [PubMed]

83. Jezek, P.; Holendova, B.; Garlid, K.D.; Jaburek, M. Mitochondrial uncoupling proteins: Subtle regulators of cellular redox signaling. Antioxid. Redox Signal. 2018, 29, 667-714. [CrossRef] [PubMed]

84. He, M.; Ma, Y.; Wang, R.; Zhang, J.; Jing, L.; Li, P.A. Deletion of mitochondrial uncoupling protein 2 exacerbates mitochondrial damage in mice subjected to cerebral ischemia and reperfusion injury under both normo- and hyperglycemic conditions. Int. J. Biol. Sci. 2020, 16, 2788-2802. [CrossRef] [PubMed]

85. del Arco, A.; Satrústegui, J. Identification of a novel human subfamily of mitochondrial carriers with calcium-binding domains. J. Biol. Chem. 2004, 279, 24701-24713. [CrossRef]

86. Satrústegui, J.; Pardo, B.; Arco, A.d. Mitochondrial transporters as novel targets for intracellular calcium signaling. Physiol. Rev. 2007, 87, 29-67. [CrossRef]

87. Aprille, J.R.; Austin, J. Regulation of the mitochondrial adenine nucleotide pool size. Arch. Biochem. Biophys. 1981, 212, 689-699. [CrossRef]

88. Ryu, J.; Ko, J.M.; Shin, C.-H. A 9-year-old korean girl with fontaine progeroid syndrome: A case report with further phenotypical delineation and description of clinical course during long-term follow-up. BMC Med. Genet. 2019, 20, 188. [CrossRef]

89. Writzl, K.; Maver, A.; Kovacic, L.; Martinez-Valero, P.; Contreras, L.; Satrustegui, J.; Castori, M.; Faivre, L.; Lapunzina, P.; van Kuilenburg, A.B.P.; et al. De novo mutations in slc25a24 cause a disorder characterized by early aging, bone dysplasia, characteristic face, and early demise. Am. J. Hum. Genet. 2017, 101, 844-855. [CrossRef]

90. Ehmke, N.; Graul-Neumann, L.; Smorag, L.; Koenig, R.; Segebrecht, L.; Magoulas, P.; Scaglia, F.; Kilic, E.; Hennig, A.F.; Adolphs, N.; et al. De novo mutations in slc25a24 cause a craniosynostosis syndrome with hypertrichosis, progeroid appearance, and mitochondrial dysfunction. Am. J. Hum. Genet. 2017, 101, 833-843. [CrossRef] 
91. Cavero, S.; Traba, J.; Del Arco, A.; Satrústegui, J. The calcium-dependent atp-mg/pi mitochondrial carrier is a target of glucoseinduced calcium signalling in saccharomyces cerevisiae. Biochem. J. 2005, 392, 537-544. [CrossRef] [PubMed]

92. Harborne, S.P.D.; King, M.S.; Crichton, P.G.; Kunji, E.R.S. Calcium regulation of the human mitochondrial atp-mg/pi carrier slc25a24 uses a locking pin mechanism. Sci. Rep. 2017, 7, 45383. [CrossRef] [PubMed]

93. Traba, J.; Satrústegui, J.; del Arco, A. Characterization of scamc-3-like/slc25a41, a novel calcium-independent mitochondrial atp-mg/pi carrier. Biochem. J. 2009, 418, 125-133. [CrossRef] [PubMed]

94. Hoffman, N.E.; Chandramoorthy, H.C.; Shanmughapriya, S.; Zhang, X.Q.; Vallem, S.; Doonan, P.J.; Malliankaraman, K.; Guo, S.; Rajan, S.; Elrod, J.W.; et al. Slc25a23 augments mitochondrial $\mathrm{Ca}^{2+}$ uptake, interacts with mcu, and induces oxidative stressmediated cell death. Mol. Biol. Cell 2014, 25, 936-947. [CrossRef]

95. Korshunov, S.S.; Skulachev, V.P.; Starkov, A.A. High protonic potential actuates a mechanism of production of reactive oxygen species in mitochondria. FEBS Lett. 1997, 416, 15-18. [CrossRef]

96. Nguyen, T.T.; Quan, X.; Hwang, K.H.; Xu, S.; Das, R.; Choi, S.K.; Wiederkehr, A.; Wollheim, C.B.; Cha, S.K.; Park, K.S Mitochondrial oxidative stress mediates high-phosphate-induced secretory defects and apoptosis in insulin-secreting cells. Am. J. Physiol. Endocrinol. Metab. 2015, 308, E933-E941. [CrossRef]

97. Bose, S.; French, S.; Evans, F.J.; Joubert, F.; Balaban, R.S. Metabolic network control of oxidative phosphorylation: Multiple roles of inorganic phosphate. J. Biol. Chem. 2003, 278, 39155-39165. [CrossRef]

98. Zhao, R.Z.; Jiang, S.; Zhang, L.; Yu, Z.B. Mitochondrial electron transport chain, ros generation and uncoupling (review). Int. J. Mol. Med. 2019, 44, 3-15. [CrossRef]

99. Hernansanz-Agustín, P.; Ramos, E.; Navarro, E.; Parada, E.; Sánchez-López, N.; Peláez-Aguado, L.; Cabrera-García, J.D.; Tello, D.; Buendia, I.; Marina, A.; et al. Mitochondrial complex i deactivation is related to superoxide production in acute hypoxia. Redox Biol. 2017, 12, 1040-1051. [CrossRef]

100. Scialò, F.; Fernández-Ayala, D.J.; Sanz, A. Role of mitochondrial reverse electron transport in ros signaling: Potential roles in health and disease. Front. Physiol. 2017, 8, 428. [CrossRef]

101. Mills, E.L.; Kelly, B.; Logan, A.; Costa, A.S.H.; Varma, M.; Bryant, C.E.; Tourlomousis, P.; Däbritz, J.H.M.; Gottlieb, E.; Latorre, I.; et al. Succinate dehydrogenase supports metabolic repurposing of mitochondria to drive inflammatory macrophages. Cell 2016, 167, 457-470.e13. [CrossRef] [PubMed]

102. Brand, M.D.; Goncalves, R.L.; Orr, A.L.; Vargas, L.; Gerencser, A.A.; Borch Jensen, M.; Wang, Y.T.; Melov, S.; Turk, C.N.; Matzen, J.T.; et al. Suppressors of superoxide-h(2)o(2) production at site i(q) of mitochondrial complex i protect against stem cell hyperplasia and ischemia-reperfusion injury. Cell Metab. 2016, 24, 582-592. [CrossRef] [PubMed]

103. Selivanov, V.A.; Zeak, J.A.; Roca, J.; Cascante, M.; Trucco, M.; Votyakova, T.V. The role of external and matrix ph in mitochondrial reactive oxygen species generation. J. Biol. Chem. 2008, 283, 29292-29300. [CrossRef]

104. Al-Aly, Z. Phosphate, oxidative stress, and nuclear factor-kb activation in vascular calcification. Kidney Int. 2011, 79, 1044-1047. [CrossRef]

105. Huang, M.; Zheng, L.; Xu, H.; Tang, D.; Lin, L.; Zhang, J.; Li, C.; Wang, W.; Yuan, Q.; Tao, L.; et al. Oxidative stress contributes to vascular calcification in patients with chronic kidney disease. J. Mol. Cell. Cardiol. 2020, 138, 256-268. [CrossRef] [PubMed]

106. Byon, C.H.; Javed, A.; Dai, Q.; Kappes, J.C.; Clemens, T.L.; Darley-Usmar, V.M.; McDonald, J.M.; Chen, Y. Oxidative stress induces vascular calcification through modulation of the osteogenic transcription factor runx2 by akt signaling. J. Biol. Chem. 2008, 283, 15319-15327. [CrossRef] [PubMed]

107. Rodenbeck, S.D.; Zarse, C.A.; McKenney-Drake, M.L.; Bruning, R.S.; Sturek, M.; Chen, N.X.; Moe, S.M. Intracellular calcium increases in vascular smooth muscle cells with progression of chronic kidney disease in a rat model. Nephrol. Dial. Transplant. 2016, 32, 450-458. [CrossRef]

108. Gordeeva, A.V.; Zvyagilskaya, R.A.; Labas, Y.A. Cross-talk between reactive oxygen species and calcium in living cells. Biochemistry 2003, 68, 1077-1080. [CrossRef]

109. Denton, R.M. Regulation of mitochondrial dehydrogenases by calcium ions. Biochim. Biophys. Acta 2009, 1787, 1309-1316. [CrossRef]

110. Stefani, D.D.; Rizzuto, R.; Pozzan, T. Enjoy the trip: Calcium in mitochondria back and forth. Annu. Rev. Biochem. 2016, 85, 161-192. [CrossRef]

111. Giorgio, V.; Burchell, V.; Schiavone, M.; Bassot, C.; Minervini, G.; Petronilli, V.; Argenton, F.; Forte, M.; Tosatto, S.; Lippe, G.; et al. $\mathrm{Ca}(2+)$ binding to $\mathrm{f}$-atp synthase $\beta$ subunit triggers the mitochondrial permeability transition. EMBO Rep. 2017, 18, 1065-1076. [CrossRef] [PubMed]

112. Tarasov, A.I.; Griffiths, E.J.; Rutter, G.A. Regulation of atp production by mitochondrial Ca(2+). Cell Calcium 2012, 52, 28-35. [CrossRef] [PubMed]

113. MacDonald, M.J.; Brown, L.J. Calcium activation of mitochondrial glycerol phosphate dehydrogenase restudied. Arch. Biochem. Biophys. 1996, 326, 79-84. [CrossRef]

114. Beis, I.; Newsholme, E.A. Effects of calcium ions on adenine nucleotide translocase from cardiac muscle. J. Mol. Cell. Cardiol. 1976, 8, 863-876. [CrossRef]

115. Bertero, E.; Maack, C. Calcium signaling and reactive oxygen species in mitochondria. Circ. Res. 2018, 122, 1460-1478. [CrossRef] [PubMed] 
116. Fernandez, E.; Bolaños, J.P. A-ketoglutarate dehydrogenase complex moonlighting: Ros signalling added to the list: An editorial highlight for 'reductions in the mitochondrial enzyme $\alpha$-ketoglutarate dehydrogenase complex in neurodegenerative diseasebeneficial or detrimental?'. J. Neurochem. 2016, 139, 689-690. [CrossRef] [PubMed]

117. Mráček, T.; Holzerová, E.; Drahota, Z.; Kovářová, N.; Vrbacký, M.; Ješina, P.; Houštěk, J. Ros generation and multiple forms of mammalian mitochondrial glycerol-3-phosphate dehydrogenase. Biochim. Biophys. Acta 2014, 1837, 98-111. [CrossRef]

118. Kowaltowski, A.J.; Castilho, R.F.; Grijalba, M.T.; Bechara, E.J.; Vercesi, A.E. Effect of inorganic phosphate concentration on the nature of inner mitochondrial membrane alterations mediated by $\mathrm{Ca}^{2+}$ ions. A proposed model for phosphate-stimulated lipid peroxidation. J. Biol. Chem. 1996, 271, 2929-2934. [CrossRef]

119. Belosludtsev, K.N.; Dubinin, M.V.; Belosludtseva, N.V.; Mironova, G.D. Mitochondrial ca2+ transport: Mechanisms, molecular structures, and role in cells. Biochemistry 2019, 84, 593-607. [CrossRef]

120. Ligeti, L.; Barlow, C.; Chance, B.; Kovach, A.G.B.; Oconnor, M. P-31 nmr-spectroscopy of brain and heart. Adv. Exp. Med. Biol. 1983, 159, 281-292.

121. Duvvuri, B.; Lood, C. Mitochondrial calcification. Immunometabolism 2021, 3, e210008. [CrossRef] [PubMed]

122. Chalmers, S.; Nicholls, D.G. The relationship between free and total calcium concentrations in the matrix of liver and brain mitochondria. J. Biol. Chem. 2003, 278, 19062-19070. [CrossRef] [PubMed]

123. Wei, A.-C.; Liu, T.; Winslow, R.L.; O'Rourke, B. Dynamics of matrix-free $\mathrm{Ca}^{2+}$ in cardiac mitochondria: Two components of ca2+ uptake and role of phosphate buffering. J. Gen. Physiol. 2012, 139, 465-478. [CrossRef] [PubMed]

124. Kawai, M.; Kinoshita, S.; Ozono, K.; Michigami, T. Inorganic phosphate activates the akt/mtorc1 pathway and shortens the life span of an $\alpha$-klotho-deficient model. J. Am. Soc. Nephrol. 2016, 27, 2810-2824. [CrossRef] [PubMed]

125. Woo, Y.; Lee, H.J.; Jung, Y.M.; Jung, Y.J. Mtor-mediated antioxidant activation in solid tumor radioresistance. J. Oncol. 2019, 2019, 5956867. [CrossRef]

126. Zhao, M.M.; Xu, M.J.; Cai, Y.; Zhao, G.; Guan, Y.; Kong, W.; Tang, C.; Wang, X. Mitochondrial reactive oxygen species promote p65 nuclear translocation mediating high-phosphate-induced vascular calcification in vitro and in vivo. Kidney Int. 2011, 79, 1071-1079. [CrossRef]

127. Agharazii, M.; St-Louis, R.; Gautier-Bastien, A.; Ung, R.V.; Mokas, S.; Larivière, R.; Richard, D.E. Inflammatory cytokines and reactive oxygen species as mediators of chronic kidney disease-related vascular calcification. Am. J. Hypertens. 2015, 28, 746-755. [CrossRef]

128. Liberman, M.; Bassi, E.; Martinatti, M.K.; Lario, F.C.; Wosniak, J., Jr.; Pomerantzeff, P.M.; Laurindo, F.R. Oxidant generation predominates around calcifying foci and enhances progression of aortic valve calcification. Arterioscler. Thromb. Vasc. Biol. 2008, 28, 463-470. [CrossRef]

129. Berridge, M.J. Vitamin d, reactive oxygen species and calcium signalling in ageing and disease. Philos. Trans. R. Soc. Lond. B Biol. Sci. 2016, 371, 20150434. [CrossRef]

130. Yoshida, T.; Yamashita, M.; Horimai, C.; Hayashi, M. Smooth muscle-selective nuclear factor-kb inhibition reduces phosphateinduced arterial medial calcification in mice with chronic kidney disease. J. Am. Heart Assoc. 2017, 6, e007248. [CrossRef]

131. Speer, M.Y.; Yang, H.-Y.; Brabb, T.; Leaf, E.; Look, A.; Lin, W.-L.; Frutkin, A.; Dichek, D.; Giachelli, C.M. Smooth muscle cells give rise to osteochondrogenic precursors and chondrocytes in calcifying arteries. Circ. Res. 2009, 104, 733-741. [CrossRef] [PubMed]

132. Chavkin, N.W.; Chia, J.J.; Crouthamel, M.H.; Giachelli, C.M. Phosphate uptake-independent signaling functions of the type iii sodium-dependent phosphate transporter, pit-1, in vascular smooth muscle cells. Exp. Cell Res. 2015, 333, 39-48. [CrossRef] [PubMed]

133. Matsushita, T.; Chan, Y.Y.; Kawanami, A.; Balmes, G.; Landreth, G.E.; Murakami, S. Extracellular signal-regulated kinase 1 (erk1) and erk2 play essential roles in osteoblast differentiation and in supporting osteoclastogenesis. Mol. Cell. Biol. 2009, 29, 5843-5857. [CrossRef] [PubMed]

134. Ge, C.; Xiao, G.; Jiang, D.; Yang, Q.; Hatch, N.E.; Roca, H.; Franceschi, R.T. Identification and functional characterization of erk/mapk phosphorylation sites in the runx2 transcription factor. J. Biol. Chem. 2009, 284, 32533-32543. [CrossRef]

135. Xiao, G.; Jiang, D.; Thomas, P.; Benson, M.D.; Guan, K.; Karsenty, G.; Franceschi, R.T. Mapk pathways activate and phosphorylate the osteoblast-specific transcription factor, cbfa1. J. Biol. Chem. 2000, 275, 4453-4459. [CrossRef]

136. Zeng, P.; Yang, J.; Liu, L.; Yang, X.; Yao, Z.; Ma, C.; Zhu, H.; Su, J.; Zhao, Q.; Feng, K.; et al. Erk1/2 inhibition reduces vascular calcification by activating mir-126-3p-dkk1/lrp6 pathway. Theranostics 2021, 11, 1129-1146. [CrossRef]

137. Chen, Y.; Duan, Y.; Yang, X.; Sun, L.; Liu, M.; Wang, Q.; Ma, X.; Zhang, W.; Li, X.; Hu, W.; et al. Inhibition of erk1/2 and activation of lxr synergistically reduce atherosclerotic lesions in apoe-deficient mice. Arterioscler. Thromb. Vasc. Biol. 2015, 35, 948-959. [CrossRef]

138. Alkagiet, S.; Tziomalos, K. Vascular calcification: The role of micrornas. Biomol. Concepts 2017, 8, 119-123. [CrossRef]

139. Jansen, F.; Stumpf, T.; Proebsting, S.; Franklin, B.S.; Wenzel, D.; Pfeifer, P.; Flender, A.; Schmitz, T.; Yang, X.; Fleischmann, B.K.; et al. Intercellular transfer of mir-126-3p by endothelial microparticles reduces vascular smooth muscle cell proliferation and limits neointima formation by inhibiting lrp6. J. Mol. Cell. Cardiol. 2017, 104, 43-52. [CrossRef]

140. Deng, L.; Huang, L.; Sun, Y.; Heath, J.M.; Wu, H.; Chen, Y. Inhibition of foxo1/3 promotes vascular calcification. Arterioscler. Thromb. Vasc. Biol. 2015, 35, 175-183. [CrossRef]

141. Cui, L.; Bai, Y.; Zhang, J.; Zhang, S.; Xu, J. Effects of extracellular acid stimulation on rat vascular smooth muscle cell in gas6/axl or pi3k/akt signaling pathway. Clin. Exp. Hypertens. 2016, 38, 451-456. [CrossRef] [PubMed] 
142. Ponnusamy, A.; Sinha, S.; Hyde, G.D.; Borland, S.J.; Taylor, R.F.; Pond, E.; Eyre, H.J.; Inkson, C.A.; Gilmore, A.; Ashton, N.; et al. Fti-277 inhibits smooth muscle cell calcification by up-regulating pi3k/akt signaling and inhibiting apoptosis. PLoS ONE 2018, 13, e0196232. [CrossRef] [PubMed]

143. Li, M.; Chiu, J.F.; Gagne, J.; Fukagawa, N.K. Age-related differences in insulin-like growth factor-1 receptor signaling regulates akt/foxo3a and erk/fos pathways in vascular smooth muscle cells. J. Cell. Physiol. 2008, 217, 377-387. [CrossRef] [PubMed]

144. Li, Y.; Sun, W.; Saaoud, F.; Wang, Y.; Wang, Q.; Hodge, J.; Hui, Y.; Yin, S.; Lessner, S.M.; Kong, X.; et al. Mir155 modulates vascular calcification by regulating akt-foxo3a signalling and apoptosis in vascular smooth muscle cells. J. Cell. Mol. Med. 2021, 25, 535-548. [CrossRef] [PubMed]

145. Kim, J.H.; Choi, T.G.; Park, S.; Yun, H.R.; Nguyen, N.N.Y.; Jo, Y.H.; Jang, M.; Kim, J.; Kim, J.; Kang, I.; et al. Mitochondrial ros-derived pten oxidation activates pi3k pathway for mtor-induced myogenic autophagy. Cell Death Differ. 2018, 25, 1921-1937. [CrossRef]

146. Furmanik, M.; van Gorp, R.; Whitehead, M.; Ahmad, S.; Bordoloi, J.; Kapustin, A.; Schurgers, L.J.; Shanahan, C.M. Endoplasmic reticulum stress mediates vascular smooth muscle cell calcification via increased release of grp78 (glucose-regulated protein, 78 kda)-loaded extracellular vesicles. Arterioscler. Thromb. Vasc. Biol. 2021, 41, 898-914. [CrossRef]

147. Panda, D.K.; Bai, X.; Sabbagh, Y.; Zhang, Y.; Zaun, H.-C.; Karellis, A.; Koromilas, A.E.; Lipman, M.L.; Karaplis, A.C. Defective interplay between mtorc1 activity and endoplasmic reticulum stress-unfolded protein response in uremic vascular calcification. Am. J. Physiol. -Renal Physiol. 2018, 314, F1046-F1061. [CrossRef]

148. Ly, L.D.; Xu, S.; Choi, S.K.; Ha, C.M.; Thoudam, T.; Cha, S.K.; Wiederkehr, A.; Wollheim, C.B.; Lee, I.K.; Park, K.S. Oxidative stress and calcium dysregulation by palmitate in type 2 diabetes. Exp. Mol. Med. 2017, 49, e291. [CrossRef]

149. Duan, X.; Zhou, Y.; Teng, X.; Tang, C.; Qi, Y. Endoplasmic reticulum stress-mediated apoptosis is activated in vascular calcification. Biochem. Biophys. Res. Commun. 2009, 387, 694-699. [CrossRef]

150. Masuda, M.; Miyazaki-Anzai, S.; Levi, M.; Ting, T.C.; Miyazaki, M. Perk-eif2 $\alpha$-atf4-chop signaling contributes to tnf $\alpha$-induced vascular calcification. J. Am. Heart Assoc. 2013, 2, e000238. [CrossRef]

151. Miyazaki-Anzai, S.; Masuda, M.; Demos-Davies, K.M.; Keenan, A.L.; Saunders, S.J.; Masuda, R.; Jablonski, K.; Cavasin, M.A.; Kendrick, J.; Chonchol, M.; et al. Endoplasmic reticulum stress effector ccaat/enhancer-binding protein homologous protein (chop) regulates chronic kidney disease-induced vascular calcification. J. Am. Heart Assoc. 2014, 3, e000949. [CrossRef] [PubMed]

152. Liberman, M.; Johnson, R.C.; Handy, D.E.; Loscalzo, J.; Leopold, J.A. Bone morphogenetic protein-2 activates nadph oxidase to increase endoplasmic reticulum stress and human coronary artery smooth muscle cell calcification. Biochem. Biophys. Res. Commun. 2011, 413, 436-441. [CrossRef] [PubMed] 